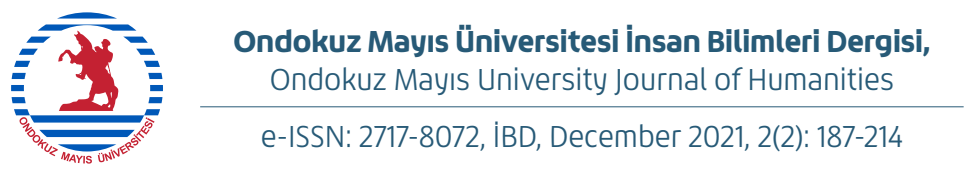

\title{
Osmanlı Rumeli'sinde Paylaşılamayan Vakıf: Hâşim Bey Camii Vakfı
}

\section{The Most Desired Vaqf in Ottoman Rumelia: Hâşim Bey Mosque Vaqf}

\author{
Doç. Dr. Hüseyin Baha ÖZTUNÇ \\ 1 Tokat Gaziosmanpaşa Üniversitesi Fen-Edebiyat Fakültesi \\ •bahaoztunc@gmail.com•ORCID > 0000-0002-6995-633X
}

\author{
Makale Bilgisi / Article Information \\ Makale Türü / Article Types: Araştırma Makalesi / Research Article \\ Geliş Tarihi / Received: 9 Kasım / November 2021 \\ Kabul Tarihi / Accepted: 29 Kasım / November 2021 \\ Yil/Year: 2021 | Cilt-Volume: 2 | Sayı - Issue: 2 | Sayfa / Pages: 187-214
}

Atıf/Cite as: Öztunç, H. B., "Osmanlı Rumeli'sinde Paylaşılamayan Vakıf: Hâşim Bey Camii Vakfı - The Most Desired Vaqf in Ottoman Rumelia: Hâșim Bey Mosque Vaqf", Ondokuz Mayıs Üniversitesi Insan Bilimleri Dergisi - Ondokuz Mayıs University Journal of Humanities, 2 (2), Aralık 2021: 187-214.

https://10.51533/insanbilimleri.1021424 


\section{OSMANLI RUMELI'SINDE PAYLAŞILAMAYAN VAKIF: HÂŞIM BEY CAMII VAKFI}

\section{THE MOST DESIRED VAQF IN OTTOMAN RUMELIA: HÂŞIM BEY MOSQUE VAQF}

ÖZ:

İslâmiyet'in önemli kurumlarından birisi olan vakıf kurumu, Osmanlı Devleti'nde büyük gelişim göstermiş ve devletin en önemli kurumlarından birisi olmuştu. Devlet ekonomisindeki bozulmalar neticesinde vakıf gelirlerinin vakıf şartlarından başka yerlere harcanmaya başlamasıyla ortaya çıkan problemler özellikle 19. yüzyılın ikinci yarısından itibaren oldukça artmıştı. Çalışma, Osmanlı Rumeli’sinde Serfice sancağına tabi Kayalar kasabasında Mehmed Hâşim Bey'in yaptırdığg cami ve kurduğu vakıf gelirlerinin aradan dört yüz sene geçtikten sonra yerinde harcanıp harcanmadığ 1 noktasında oluşan ihtilâfı açığa çıkarmayı hedeflemektedir. Bu amaçla, öncelikle vakıfla ilgili bilgi verilerek gelir getiren akar tespit edilecek ve akabinde ortaya çıkan ihtilaf tüm yönleriyle ele alınmaya çalışılacaktır.

Anahtar Kelimeler: Osmanl Devleti, Vakıf, Serfice, Kayalar, Evkâf-ı Münderise.

\section{ABSTRACT:}

The vaqf institution, which is one of the important institutions of Islam, developed greatly in the Ottoman Empire and became one of the most important institutions of the State. As a result of the deterioration in the state economy, the problems that arose when the vaqf revenues started to be spent in other places than the conditions of the vaqf, especially since the second half of the 19 th century. The study aims to reveal the controversy over whether the income of the mosque built by Mehmed Hâşim Bey and the vaqf he established in the town of Kayalar, which is subject to the Serfice Sanjak in Ottoman Rumelia, was spent instead of it after four hundred years. For this purpose, first of all, some information about the vaqf will be provided and its source of income will be determined, and then the resulting conflict will be focused in all its aspects.

Keywords: Ottoman Empire, Vaqf, Serfice, Kayalar, Evkâf-ı Münderise. 


\section{GíRiş}

Önemli bir İslâmî hayır kurumu olan vakıf, Türklerin İslamiyet'i kabulüyle birlikte Türk Devletlerinde de yaygın olarak görülür. Osmanlı Devleti, vakıfları dinî ve hayrî bir müessese olarak öyle bir noktaya ulaştırmıştır ki, araştırmacılar tarafından "Vakıf Medeniyeti” olarak adlandırılmıştır. Sosyal hayattaki pek çok hizmetin halka ulaştırılması noktasında hayatî rol üstlenen vakıflar zamanla bozulmaya başlamıştı. Bu bozulmanın etkileri her ne kadar daha sonraki yüzyıllarda etkisini fazlaca gösterse de Mehmet Öz, henüz XVII. yüzyılın başında Osmanlı Devleti'ndeki bozulmayla ilgili risale kaleme alan Koçibey'in risalesinde şeriata aykırı temlik ve vakıflar konusu üzerinde çok fazla durulduğunu ifade etmektedir. ${ }^{[1]}$ Mustafa Alkan da bozulma sebeplerini; Timar/mîrî arazilerin vakıf hale getirilmesi, Evlatlık/zürrî vakıfların yaygınlaşması, vakıfların gayrimenkul olma şartının ortadan kalkması, mukataa, icareteyn ve gedik sistemlerinin suistimalleri ve vakıf kurumları: inşâ bakım ve tasfiye başlıkları altında açıklamaktadır. ${ }^{[2]}$ II. Mahmud zamanında 1826 yılında Evkâf-ı Hümâyun Nezareti kuruldu. Bu yeni müessesenin kuruluş nedenleri arasında; dağınık durumdaki vakıfların tel elde toplanması, vakıflarda gittikçe artan yolsuzlukların önlenmesi, vakıf potansiyelinden devletin diğer sektörlerinde faydalanma düşüncesi, dinî çevrelerin gücünü kırma, vakıflardaki keyfiliğe son verme, vakıfların yönetimini hem halk hem de vakıf kurumu lehine 1 slah etme, vakıflar arası kaynak aktarımı yapabilme fikri yer almaktaydı. ${ }^{[3]}$ Nezaretin kuruluş amacı her ne kadar yukarıdaki gibi iyi niyetler taşısa da Osmanlı Devleti’nde kendisini gittikçe hissettiren ekonomik sıkıntılar vakıf kurumunu da olumsuz etkilemişti. Ekonomideki bozulmayla beraber vakıf gelirleri de amacından farklı yerlerde kullanılmaya başlanmıştı. Askerî harcamalar başta olmak üzere para gerektiren pek çok noktada vakıf gelirlerinden bu kalemlere para aktarılıyordu. Vakıfların gelirlerinden diğer sektörlere para aktarımının Nezaretin kuruluş yılı olan 1826 yılında başladığı görülmektedir. Eyüp’te kurulan iplik fabrikası binalarının yapımı ve makinelerin temini ve montajı için 1826-1833 yıları arasında Evkâf Hazinesi’nden 1.134.294 kuruş 76 para aktarılmıştı. Vakıf paralarının Mîrî Hazine'ye aktarılması nedeniyle paraya ihtiyaç duyan vakıfların onarım ve inşâ gibi masrafları için Evkâf Hazinesi'nden para temini imkânsız hale gelmişti. ${ }^{[4]}$ Çalışma, Kayalar kasabasında Hâşim Bey tarafindan yaptırılan Hâşim Bey Camii’ne gelir getirmek için vakfedilen akarlar üzerindeki ihtilafı vakıf müessesesi ve uygulama örnekleri üzerinden ele almaktadır.

1 Mehmet Öz, "Gelenekçi Osmanlı Islahat Düşüncesinde Temlikler ve Vakıflar”, Vakıflar Dergisi 80. Yıl Özel Sayısı, Ankara 2019, s. 108.

2 Mustafa Alkan, “Osmanlı Vakıf Sisteminde Bozulma Üzerine Bazı Düşünceler, Türk Dünyası Araştırmaları, S. 166, Şubat 2007, s. 70-71.

3 Nazif Öztürk, "Evkâf-ı Hümâyun Nezâreti”, Diyanet Vakfı Islâm Ansiklopedisi, C. 11, Türkiye Diyanet Vakfı Yayınları, İstanbul 1995, s. 522.

4 Nazif Öztürk, "XIX. Asır Osmanlı Yönetiminde Yaşanan Batılılaşma Hareketlerinin Vakıfların Üzerindeki Etkileri", İslâmî Araştırmalar Dergisi, C. 8, S. 1, Ankara 1995, s. 19. 


\section{Serfice-Kayalar:}

Çalışmanın konusunu ihtiva eden vakıf, Osmanlı Devleti'nin Rumeli coğrafyasında bulunan Serfice sancağına bağlı Cumapazarı-Hasanoba bir diğer adıyla Kayalar kasabasında bulunmaktaydı. Klasik dönemde Paşa Livası'na bağlı bir yerleşim yeri olarak idarî taksimatta yerini alan Serfice ${ }^{[5]}$ yi 1661 Mayıs ayında ziyaret eden Evliya Çelebi şu bilgileri vermektedir: Selfice de denilen yerleşim merkezinde bir kale bulunmaktadır. Nişancı Paşa Hassı olan Serfice'de kalesinde 100 kadar Rum evinden başka bir yapısı olmayıp bütün imareti aşağı şehirdedir. Altı Müslüman, Sekiz Rum ve Bir Yahudi mahallesi bulunmaktadır. Şehirde altı cami ve altı mahalle mescidi olup, medrese ve aşevi imaretleri bulunmamaktadır. Bir Halvetî tekkesi, iki sıbyan mektebi, bir han, bir hamam ve 100 kadar da dükkânı vardır. ${ }^{[6]}$ Serfice, 1836 yılında merkezi Manastır olan Rumeli Eyaleti’nin sınırları içinde kalmaktaydı. 1844/1845 (1260) yılında Manastır eyaleti lağvedilmiş, Serfice ise yine Rumeli eyaleti sınırları içinde kalmış ve 1855/1856 (1270) yılında yeniden teşkil edilen Manastır vilayeti bünyesinde kaza merkezi olarak yerini almıştı. ${ }^{[7]}$ Vakfın bulunduğu Kayalar kasabasıyla ilgili Şemseddin Sami, buranın Cuma ya da $\mathrm{Cu}$ mapazarı olarak da adlandırıldığını ifade ederken ${ }^{[8]}$, yerleşimiyle ilgili olarak da Serfice'nin 30 kilometre kuzeybatısında, Manastır'ın 80 kilometre güneybatısında olduğu, güneyinde Kozana, batısında Kesriye ve Nasliç, kuzeyinde Filorina kazalarıyla doğusunda Selânik vilayeti sınırıyla çevrili olduğunu belirtir. Yine Şemsedin Sami’nin tespitlerine göre, XIX. yüzyılın sonlarında nüfusu 2865 olup merkezde üç adet cami, bir rüştiye ve bir ibtidaî mektebi, 25 dükkân, 10 han ve bir kışla bulunmaktadır. ${ }^{[9]} \mathrm{Bu}$ camilerden birisi çalışmanın konusunu teşkil eden Hâşim Bey'in yaptırdığı ve kendi adıyla anılan Hâşim Bey Camii’dir.

\section{Haşim Bey Camii ve Vakfı:}

Cami ve vakfın kurucusu Hâşim Bey'le ilgili yapılan arşiv araştırmasında herhangi bir bilgiye ulaşılamadı. Şu anda ayakta olmayan caminin yapılış tarihi tam olarak bilinmemektedir. Gerek Cumhurbaşkanlığı Devlet Arşivleri’nde gerekse Vakıflar Genel Müdürlügünde yapılan arşiv taramalarında caminin vakfiyesine rastlanamamıştır. Caminin yapılış tarihiyle ilgili çalışmaya konu olan dönemdeki vakıf mütevellisi Osman Nûri farklı bilgiler verdiğinden yaklaşık bir tarih belirle-

5 İbrahim Sezgin, "Paşa Livası", Diyanet Vakfı Islâm Ansiklopedisi, C. 34, Türkiye Diyanet Vakfı Yayınları, Istanbul 2007, s. 184.

6 Günümüz Türkçesiyle Evliya Çelebi Seyahatnamesi: Akkirman-Belgrad-Gelibolu-Manastır-Özü-Saraybosna-Slovenya-Tokat-Üsküp, 5. Kitap, 2. Cilt, Yay. Haz. Seyit Ali Kahraman, Yapı Kredi Yayınları, İstanbul 2010, s. 810-812.

7 H. Baha Öztunç, Tanzimat Döneminde Bir Rumeli Şehri Manastır Sosyo-Ekonomik Yapı (1839-1876), Kitabevi Yayınları, İstanbul 2020, s. 29-30-35-36.

8 Şemseddin Sami, Kâmusu'l-A'lâm, C. V, Mihran Matbaası, İstanbul 1314, s. 3794.

9 Şemseddin Sami, a.g.e., C. III, Mihran Matbaası, ístanbul 1308, s. 1835. 
mek de bu manada mümkün olamamaktadır. Şöyle ki Osman Nuri’nin bahsettiği ilk tarihe göre caminin yapım zamanı, 15. yüzyılın ikinci yarısı olarak tarihlendirilebilir. Bu tarihlendirmede Hâşim Bey vakfı mütevellisi Yüzbaşı Osman Nuri’nin şu ifadeleri delil teşkil eder: "Manastır vilâyeti dâhilinde Cumabazarı Hasan Oba nâm-1 diğer Kayalar kasabasında ecdâd-1 çâkerânemden müteveffâ Hâşim Beyin dört yüz seneyi mütecâviz binâ ve ihyâ-kerdesi olan câmi'-i şerîfle meşrûta olmak üzere..."[10] . Ancak Osman Nuri başka bir belgede ise "Serfice sancağ dahilinde Cum'a kazâsına tâbi' Hasanobası nâm karyede vâki' ceddim bundan yüz altmış beș sene mukaddemleri merhûm Hâşim Bey’in binâ ve ihyâ eylediği câmi'-i șerîfi..." ifadelerini kullanır. ${ }^{[1]]}$ Bununla birlikte caminin yapılış tarihiyle ilgili belgelerin tümü dikkate alındığında bir belge hariç tarih zikredilen bütün belgelerde dört yüz seneden fazla olduğuna vurgu yapıldığından caminin 15 . yüzyılın ikinci yarısında yapıldığı bilgisinin doğru olduğu kanaatine varılmaktadır.

Arşiv taramalarından Hâşim Bey vakfına dair bulunabilen en eski tarihli kayıt 4 Haziran 1742 tarihli bir berât-1 şerîf suretidir. Belgede Hâşim Bey’in yaptırdığı cami hareminin yakınında hafta pazarının bulunduğu yerde vakfedilen arsadan elde edilen kiraların caminin imam, hatip, müezzin ve kayyımının maaşları ve yine caminin tamiri, aydınlatma ve hasırları için harcanacağı belirtilir. Bu masraflardan sonra artan paradan günlük 4 akçe vakfın mütevellisine verilecekti. O dönem Mütevelli olan Hüseyin vefât etmiş ve yerine oğlu İsmâil'in "devâm-1 ömr" kaydıyla geçmesi uygun bulunmuştu. ${ }^{[12]}$

\section{Vakıf Gelirlerine Yapılan Müdahale:}

Çalışmanın ana konusunun vakıf gelirlerine yapılan müdahale olduğu daha önce ifade edilmişti. Bu müdahaleden dolayı ortaya çıkan ihtilafın bir tarafında vakfın mütevellisi, diğer tarafında ise Kayalar eşrâfından Cemal Bey bulunmaktadır. İhtilaf özetle Cemal Bey’in vakıf gelirlerine müdahalesi neticesinde meydana gelmekteydi. Cemal Bey vakfın münderis vakıf haline geldiğinden tutun da mütevellisinin vakfı zarar uğrattığına kadar pek çok gerekçe öne sürerek vakıf gelirlerini kendilerinin daha iyi idare ettiği ve buradan da eğitime para ayrıldığını iddia etmekteydi.

İhtilafın meydana çıktığı zaman diliminde vakıf mütevellisi olan Osman Nûri Bey de bu iddialara karşı çıkarak vakfa yapılan müdahaleyi engellemek için uzun süre çaba gösterecekti. Cemal Bey, Kayalar’nn nüfuzlu kişilerinden olup burada yaptığ faaliyetlerle tanınmaktadır. Cemal Bey’e verilen rütbe-i sâlise ile ilgili Manastır

10 Türkiye Cumhuriyeti Cumhurbaşkanlığı Devlet Arşivi Başkanlığı Osmanlı Arşivi (BOA), Bâb-ı Ali Evrak OdaSI (BEO), 194/14518, leff 2, 13 Nisan 1309 (25 Nisan 1893).

11 BOA, Evkaf Cihat Kalemi (EV. MKT. CHT), 234/23, leff 1, Fi 25 Kânûn-ı Evvel 1303 (6 Ocak 1888).

12 BOA, Evkaf Mektubi Kalemi (EV. MKT), 2030/4, leff 3, 31 Mayıs 1308 (12 Haziran 1892). 
Valisi Mehmed Fâik tarafından Dahiliye Nezaretine gönderilen belgede; kendisi "Cum'a kazâsı merkezi olan Kayalar kasabası hânedânından” olarak adlandırılmış olup önemli işlerde ve özellikle de 1890/1891 (1306) yılının a'şâr ihâlesinin gerçekleştirilmesi esnasında hazine menfaatine gösterdiği yararlılığın önemine vurgu yapılmaktadır. Aynı belgede Cemal Bey'in devletine sadık olduğu ve hükûmete yardımda bulunduğu ifade edilerek rütbe-i sâlise ile taltifinin uygun olduğu belirtilmektedir. ${ }^{[13]}$ Kayalar'ın ileri gelenlerinden olan Cemal Bey'in eşi Fatıma Hanım ve annesi Şirin Hanım’n da sonraki yıllarda ikinci rütbeden şefkat nişanı aldığı görülmektedir. ${ }^{[14]}$ Cemal Bey, 1897 Türk-Yunan Savaşı sırasında Zülfikar Efendi’yle beraber askerî sevkiyat komisyonunun başında bulunmuşlar ve çok sayıda malzemeyi başarıyla nakletmişlerdi. Cemal Bey kendi konağını hastane olarak hizmete açmış, yaralı askerleri tedavilerinin akabinde Soroviç’e naklettirmişti. ${ }^{[15]}$ Tüm bu faaliyetlerinin yanında eğitim alanında da Kayalar'da önemli hizmetlerde bulunan Cemal Bey'in çalışmanın konusuyla ilgili faaliyetleri de eğitime gelir getirmek amacıyla yaptıklarıyla ilişsilidir. Cemal Bey, Haşim Bey evkafını, sadaka tevliyeti olarak değerlendirilerek gelirlerinin Evkâf-1 Münderise Nizamnamesi kapsamında Haşim Bey vakfının gelirlerinden maarife kaynak ayrılmasında öncülük etmişti. Padişah iradesiyle yürürlüğe giren 4 Ekim 1882 tarihli Evkâf-1 Münderise Talimatnamesi hükmünce eğer bir vakfın tevliyeti sadaka tevliyeti statüsündeyse hayrat ve meberratı mevcut olanları ya da münderis olup da cami, medrese, mektep, çeşme ve köprü gibi herkesin yararlandığı birimleri bulunan vakıflar imar ve ihya ettirilirdi. Vakfın fazla gelirlerinden bir miktarı mütevellisine tahsis edilerek gerisi maarif sandığına nakledilirdi. ${ }^{[16]}$ Hilmi Paşa’nın Rumeli’de sürdürülen eğitim için hazırladığı raporda da maarif gelirleri için evkâf-1 münderisenin kullanılması yer almaktaydı. Böylelikle maarif hisse-i ianesi ve evkâf-1 münderise gelirleri maarife aktarilacakt1. ${ }^{[1]]}$

İhtilafın diğer tarafındaki kişi ise vakıf mütevellisi, Hassa Redif 4. Alay 3. Tabur 1. Bölükte görevli Yüzbaşı Osman Nuri’ydi. Kendisinin mütevelli atanmasına dair yazı; "Serfice sancağı dâhilinde Cum'a nâm-1 diğer Kayalar kasabasında merhûm Hâşim Bey’in binâ eylediği câmi'-i şerîf vakfının vazîfe-i mu'ayyene ile tevliyet ciheti mutasarrıfı Mahmud'un bilâ-veled mahlûlünden Osman Nuri bin Ahmed

13 BOA, İrade Dahiliye (İ. DH), 1242/97298, leff 1, 27 Mayıs 1307 (8 Haziran 1891). Cemal Bey'e rütbe-i sâlise verilmesi ile ilgili irade 19 Eylül 1891 tarihinde sadrazam tarafından padişaha sunuldu ve bir gün sonra padişah tarafından da kabul edildi Aynı Belge, leff 5, 8 Eylül 1307 (20 Eylül 1891).

14 BOA, Irrade Taltifat (İ. TAL), 227/51, 4 Teşrîn-i Evvel 1316 (17 Ekim 1900).

15 H. Baha Öztunç, Rumeli II. Abdülhamid Döneminde Bir Muhabirin Rumeli İzlenimleri (1896-1907), Kitabevi Yayınları, İstanbul, 2020, s. 313-322.

16 Yakup Karataş, "Sultan II. Abdülhamid’in Eğitim Politikalarının Mali Bir Veçhesi: Evkâf-ı Münderisenin Maarife Terki”, Atatürk Üniversitesi Türkiyat Araştırmaları Enstitüsü Dergisi, S. 57, 2016, s. 1843.

17 Ahmet Köksal, Maarife Kaynak Olarak Evkâf-ı Münderise, Serander Yayınları, Trabzon 2019, s. 24-26. 
Efendi uhdesine tevcîhine dâ'ir" ifadeleriyle 4 Kasım 1890 tarihlidir. ${ }^{[18]}$ Osman Nuri Bey bu tarihten itibaren vakıf mütevellisi olsa da daha önce de "mütevelli kaymakamlığı” vazifesini yaptığından vakıfla ilgilenmekte ve vakfa gelir getiren akarların kullanım haklarıyla ilgili girişimlerde bulunmaktaydı.

İki taraf arasındaki ihtilaf vakfa gelir getiren akarlardan elde edilen gelirlerin başka yerlere harcanmasıyla ilgiliydi. Konuyla ilgili arşivde tespit edilebilen en erken tarihli belge 27 Ekim 1884'tür. Serfice mutasarrıflığından Maarif Nezaretine gönderilen ilgi yazıda, Mutasarrıf Halil Bey'in gayretleri neticesinde Kayalar'da her biri 200 öğrenci kapasiteli iki iptidai mektebi inşaatının başlatıldığı haber verilmekteydi. İnşaat masrafları orada yaşayan halk tarafından karşılanacaktı. Ayrıca Kayalar'da olup meşrûtun-lehi ${ }^{[19]}$ münderis olan ve irade gereğince gelirinin maarife aktarılması gereken, müzayede ile senelik kirası 27.500 kuruşa çıkartılan dükkânlardan alınacak kira geliri de bu okullar için harcanacaktı. ${ }^{[20]}$ Burada her ne kadar ismen zikredilmese de münderis olan vakıf, Haşim Bey vakfı ve senelik 27.500 kuruş gelir getiren dükkânlar da bu vakfa şart edilen dükkânlardı. Aynı belgenin arkasında Maarif Nezareti Mekâtib-i ibtidaiye Müdüriyeti mührüyle 13 Aralık 1884 tarihli bir cevap yazısı kaleme alınmıştı. Burada okulların yapımı için sayılan gelirler arasında gösterilen dükkân kiralarıyla ilgili; söz konusu dükkanların kaç adet olduğu, gelirinin hangi vakıf ya da vakıf esere tahsis edildiği ile vakıf dükkanların vakfiyesi var ise gönderilmesinin uygun olacağı bildiriliyordu. Ayrıca bu mümkün olmazsa eskiden beri uygulanan teamülün bildirilmesinin gerekliliği gibi bilgiler Serfice mutasarrıflığından talep edilmekteydi. ${ }^{[21]}$ Serfice mutasarrıflığ bölgede bulunan münderis evkafın gelirlerinin eğitime tahsis edildiği; ancak bu uygulamalarına yönelik bir müddet sonra davalar açıldığını ifade etmektedir. Tek amaçlarının eğitimin ilerlemesi olduğu ve bunu sağlamak için aldıkları kararlardan ötürü mahkemeye çıkmayı ve eğitim için ayrılan parayı mahkeme masrafları için kullanmak zorunda olduklarını belirten mutasarrıf Halil Bey, merkez liva maarif başkanının bundan dolayı istifa ettiğini ve kimsenin bu görevi istemediğini de dile getirir. Halil Bey yazısına bu gibi durumlarda olayın Maarif ve Evkâf Nezaretleri arasında yapılacak yazışmalar neticesinde alınacak kararlarla çözülmesinin doğru olduğu ve bunun için de Adliye ve Evkâf Nezaretlerine gerekli tebligatın yapılmas1 önerisiyle son verir. ${ }^{[22]}$ Mutasarrıf Halil Bey'in önerisine cevap olarak "evkâf-1 münderise" işlerinden dolayı müddeilerle maarif memurları arasında meydana

18 VGM Defter, 1838. 2; Vakıflardaki cihet mevzuatıyla ilgili ayrıntılı bilgi için bk. Talip Ayar, "Cihât Mevzuatı", Vakıflar Dergisi, S. 48, Aralık 2017, s. 145-193.

19 Meşrutün Leh; Vâkıf tarafından vakfın menfaati kendisine şart olunan cihettir. Mesela, vâkıf vakfeylediği hanın varidatını bir medresenin müderris ve talebesine veya bir camiin imam ve hatibine şart etmiş ise bunlar meşrutün-leh olmuş olurlar. bk. Ali Himmet Berki, Vakfa Dair Yazılan Eserlerle Vakfiye ve Benzeri Vesikalarda Geçen Istılah ve Tâbirler, Vakıflar Genel Müdürlüğü Neşriyatı, Ankara 1966, s. 37.

20 BOA, Marrif Tedrisat-ı Ibtidaiyye Kalemi (MF. IBT), 18/21, 15 Teşrîn-i Evvel 1300 (27 Ekim 1884).

21 BOA, MF. IBT, 18/21, 1 Kânûn-ı Evvel 1300 (13 Aralık 1884).

22 BOA, Maarif Mektubi Kalemi (MF. MKT), 91/47, leff 1, 11 Nisan 1302 (23 Nisan 1886). 
gelen anlaşmazlıklar için; anlaşmazlıkların iki nezaret arasında halledilmesinin mümkün olmadığı ifade edilmişti. ${ }^{[23]}$ Görüleceği üzere, yerel maarif idareleri bazı vakıf gelirlerini kullanmak için bunları evkâf-1 münderise olarak değerlendirmekte; ancak bunların bazılarının münderis vakıf olmadığı nedeniyle gelirlerine maarif tarafından haksız yere el konulduğunu ifade eden davalar açılmaktaydı.

Çalışmanın konusu olan Hâşim Bey Camii Vakfı gelirlerine yapılan müdahalenin engellenmesi için daha önceden iki defa yazı gönderilmişken gereğinin yapılmadığı anlaşıldığından bir an evvel ilgili işlemin tesisi Serfice mutasarrıflı̆̆ına 2 Temmuz 1887 tarihli yazıyla bildirilmişti. ${ }^{[24]} \mathrm{O}$ tarihte Serfice mutasarrıfı olan Reşad Bey bu yazıya cevaben Kayalar’a geldiğini ve Hâşim Bey Camii hakkında gerekli tedkikatı yaptığını ve durumu merkeze bildireceğini belirtmekteydi. Yapılan inceleme neticesinde Serfice livası Evkâf Müdürü Hasan Basri şu tespitleri yapmaktaydı: Haşim Bey camisi şu anda mamur durumda olup beş vakit namaz kılınmaktadır. Vakfın gelirleri Rumi 1301, 1302 ve 1303 senelerinde Maarif Reisi Cemal Bey tarafından zapt edilmiş durumdadır. Vakfın senelik geliri 25.000 kuruş olup üç senelik geliri olan 75.000 kuruş Cemal Bey tarafından alınmıştı. Eğer bu gelirler tekrar cami için kullanılmazsa ileride cami kullanılamaz duruma gelecekti. Bu nedenle gerek Hâşim Bey Camii vakfı ve gerekse diğer vakıf gelirlerine maarif tarafından müdahale edilmemesi daha önceden de ifade edilmişse de henüz gereği yapılmamıştı. Cemal Bey elindeki 75.000 kuruşu bir an önce evkâf sandığına teslim etmesi için Serfice livası mutasarrıflı̆̆ına bir emirname gönderilmesi uygun olacaktır. ${ }^{[25]}$ Hasan Basri Bey'in bu tespitlerinden yaklaşık bir buçuk ay sonra Serfice mutasarrıfı Reşad Bey, Evkâf Nezaretine gönderdiği yazıda öncelikle 19 Ocak ve 10 Haziran 1885 tarihlerinde vakıf gelirlerine yapılan müdahalenin engellenmesi ile ilgili yazıya aslında 14 Ocak 1886 tarih ve 121 numaralı arîza ile cevap yazıldığını ifade etmektedir. Vakıf mütevellisi Mehmed Efendi'nin iddiaları neticesinde Kayalar maarif komisyonunda dava açılmış akabinde istinaf davası yapılmış ve bu arada Mehmed Efendi vefat etmişti. Kendisinin vefatından sonra yapılan tahkikat ve evraka göre vakfın tevliyetini üstlenmesinin çok da doğru olmadığının anlaşıldığı ve bu nedenle vakıfla ilgili kararın Evkâf ve Maarif Nezaretleri arasında verilmesinin uygun olduğu ifade edilmekteydi. Reşad Bey burada Kayalar’a gelip yaptığı incelemeye atfen, söz konusu vakıf gelirinin miktarı ve nereye harcandığıyla ilgili bir defter aldığını ve camide namaz kılındığı, malzeme ve diğer masraflarının da söz konusu gelirden harcandığg, bununla birlikte caminin tamire muhtaç durumda olduğuna dikkat çekmişti. Tüm bu işlemleri yapabilmek için de etkili bir maarif müdürünün tayinini isteyen Reşad Bey, Serficeli İsmail Efendi’nin bu görevi hakkıyla yerine getirebileceği kanaatiyle yazısına son verir. ${ }^{[26]}$ Maarif tarafından yapılan

\footnotetext{
23 BOA, MF. MKT, 91/47, leff 2, 26 Haziran 1302 (8 Temmuz 1886).

24 BOA, EV. MKT, 1391/16, leff 1, 20 Haziran 1303 (2 Temmuz 1887).

25 Aynı Belge, leff 3, 19 Haziran 1303 (1 Temmuz 1887).

26 Aynı Belge, leff 4, 6 Ağustos 1303 (18 Ağustos 1887).
} 
müdahale nedeniyle gereken soruşturmanın yapılması ve bölgedeki vakıf işlerini düzenlemek üzere işinin ehli bir evkâf müdürünün tayini isteğine gelen cevapta müdür atamasının zaten yapıldığı ve gerekli tahkikatın bu müdür tarafından yapılıp neticesinin bildirilmesi gerektiği şeklindeydi. ${ }^{[27]}$ Anlaşılacağı üzere Osman Nuri Bey oldukça uzun sürecek olan vakıf gelirlerine yapılan müdahaleyle ilgili girişimlerine daha mütevelli kaymakamı olduğu tarihlerde başlamıştı. Vakıf mütevellisi olan Mehmed Bey'e mütevellilik 9 Şubat 1887 tarihinde verilmişti. Vakfın genel durumuyla ilgili "kuyûd-1 hâkân̂̂"ye müracaat edilmiş; ancak herhangi bir kayda rastlanamamıştı. ${ }^{[28]} 17$ Nisan 1888 tarihli Evkâf Nezaretine göndermiş olduğu detaylı bir yazısında; dört sene evvel (16 Ekim 1884) Haşim Bey Camii’ne vakfedilen hafta pazarı arsasından alınan kiraya yapılan müdahalenin menedilmesi ve usulünce şart olunduğu yerlere harcanması 19 Ocak 1885 tarihinde Serfice mutasarrıflı̆̆ına bildirilmişken aradan geçen dört sene boyunca vakfın gelirleri güyâ maarife aktarılmak üzere maarif reisi Cemal Bey tarafından gasp edildiği ifade edilmekteydi. Cemal Bey'in bu müdahalesi nedeniyle hem cami hizmet veremez hale gelmiş hem usule uygun davranılmamış ve hem de vakıf şartı ihlâl edilmiş durumdaydı. Vakıf mütevellisi olan Osman Nûri’nin kardeşi Mehmed Efendi, müracaat edecek hiçbir yer kalmadığından vakfın tencere ve kazanlarını satmak zorunda kalmış ve dava devam ederken aniden vefat etmişti. İki yüz seksen seneden beri ellerinde bulunan vakıf mütevelliliği vazifesiyle ilgili defterhâne-i âmirede kaydın bulunduğundan bahisle müşerref caminin harap olduğu ve tekrar müşerref hâle gelmesi için can ve mallarıyla çalışılsa da bu haliyle harap olacağı görülmekteydi. Bu nedenle vakıf akarına yapılan müdahalenin bir an evvel son bulması ve kuruluş şartlarına uygun olarak yapılan müdahalenin önlenmesi istenmekteydi. ${ }^{[29]} \mathrm{Bu}$ taleple ilgili yapılan incelemelerde; Hasanobası'nın hafta pazarının kurulduğu yerde Hâşim Bey Vakfi'na ait arsadan elde edilen gelirler caminin imam, hatip, müezzin ve kayyımının maaşlarına, caminin tamiri, aydınlatılması ve hasırları için harcanmakta ve ayrıca günlük dört akçe tevliyet ciheti de mütevellisine verilmekteydi. Buraya yapılan müdahalenin engellenmesi ve vakıf muhasebesinin yapılarak gönderilmesi Serfice mutasarrıflı̆̆ına 19 Ocak 1885 tarihinde iletilmişse de hâlen gelmediği ifade edilmişti ki tarih 12 Ağustos 188 ' $^{\prime}{ }^{\left[{ }^{[30]}\right.}$ Bu tespitten üç gün sonra Serfice mutasarrıflı̆̆1 ve Evkâf-1 Hümâyûn Müdürlüğ̈̈’ne gönderilen yazıyla ilgi müdahalenin menedilmesiyle ilgili 19 Ocak 1885 tarihinde Serfice mutasarrıflı̆̆ına tahrirat gönderildiği halde işlem yapılmadığ 1 ve söz konusu arsa gelirine mahallî maarif idaresi tarafından yapılan müdahaleyle ilgili gereğinin yapılması istenmekteydi. ${ }^{[31]}$ Aynı minvalde bir yazı da sene sonunda bu sefer Dahiliye Nezareti tarafından Serfice

27 BOA, EV. MKT, 1394/21, 9 Teşrîn-i Sânî 1303 (21 Kasım 1887).

28 BOA, EV. MKT. CHT, 234/23, leff 2, Fi 7 Kânûn-ı Evvel 1303 (19 Aralık 1887).

29 BOA, EV. MKT, 1449/126, 5 Nisan 1304 (17 Nisan 1888).

30 BOA, EV. MKT, 1394/21, 1 Ağustos 1304 (13 Ağustos 1888).

31 BOA, EV. MKT, 1450/98, 3 Ağustos 1304 (15 Ağustos 1888). 
mutasarrıflı̆̆ına iletilmişti. ${ }^{[32]}$

$\mathrm{Bu}$ yazışmalar arasında dikkati çeken iki husus bulunmaktadır ki bunlardan ilki Serfice Evkâf Müdürü Hasan Basri Bey'in vakıf gelirine Cemal Bey tarafından yapılan müdahalenin doğru olduğu ve 75.000 kuruşluk gelirin Cemal Bey tarafından gasp edildiği bilgisidir. Diğeri ise bu tespite karşı Serfice mutasarrıfı Reşad Bey'in, Cemal Bey tarafında yer almasıdır ve bunu yaparken o dönemde vakıf mütevellisi olan Mehmed Bey’in göreviyle ilgili şüpheler olduğunu ifade ederken gasp edildiği ifade edilen 75.000 kuruştan hiç bahsetmemesidir.

Üzerinde ihtilaf oluşan gelirin ne kadar olduğuna dair vakıf mütevelli ve vekillerinin yazılarının yanı sıra Evkâf Nezaretindeki defterler de bilgi vermektedir. Bunlardan Ocak 1903 tarihli bir kayıtta vakıf gelirleri ile ilgili şu bilgiler verilmekteydi:

\begin{tabular}{|c|c|}
\hline Guruş & 500 \\
\hline Nev' -i hayrât & Câmi' \\
\hline Serfice & Cum'a \\
\hline Vakıf ve Bânîsi & Hâşim Bey \\
\hline Vâridât-1 seneviyesi & 18.000 \\
\hline Mesârif-i Seneviyesi & 16.889 \\
\hline Fazla vâridât & 611 \\
\hline Evkaf türü & Mülhaka ${ }^{[33]}$ \\
\hline $\begin{array}{c}\text { İhyâsı daha ne gibi şeylere } \\
\text { muhtâc idügi }\end{array}$ & Ta ' mîrât mezkûr vâridâtından mümkün \\
idügi
\end{tabular}

Tablo 1: Haşim Bey vakfının 1903 senesi muhasebe kaydı. ${ }^{[34]}$

Vakıf gelirleri ile ilgili bu gelişmeler yaşanırken caminin de hizmet vermeye devam etmesi gerekiyordu. Caminin müezzin ve kayyımlık ciheti 1889 başlarında boş durumdaydı ve bu durum hizmetin aksamasına neden olmaktaydı. Kayalar Naibi'nin ilgi yazısında Mahallî Evkâf Müdürü Rıfat Efendi’nin de hazır bulunduğu, Kayalar kasabası ahalisinden Cemal Bey İbnü'l-merhûm Orhan Bey ve El-Hac

32 BOA, Dahiliye Mehtubi Kalemi (DH. MKT), 1580/112, 14 Kânûn-ı Evvel 1304 (26 Aralık 1888).

33 Evkâf-ı Mülhaka: Evkâf idaresinin nezaret ve mürakabesi altında olarak mütevellileri marifetiyle idare olunan vakıflardır. bk. Ali Himmet Berki, A.g.e., s. 16.

34 BOA. Evkaf Defterleri (EV. d.) 37281, s. 15, 15 Kânûn-ı Sânî 1318 (28 Ocak 1903). 
Emin Bey İbn-i Abdülkerim Bey ve Mahmud Ağa İbn-i El-Hac Ahmed ve İsmâ'il Ağa İbn-i Zeynel Ağa ve Molla Ömer bin Sâlih ve diğer kimseler Kayalar kasabası Emirhan Mahallesi'nde yaşayan 30 yaşındaki Ahmed Efendi'yi bu görev için önermekteydi. Ahmed Efendi burada sınava alınıp yeterli bulunur ve ücretini cami vakfından almak üzere aylık 100 kuruş müezzinlik ve 50 kuruş ücretle de kayyımlık görevini üstlenmesinin uygun olduğu ifade edilir. ${ }^{[35]}$ İlgili atama isteği, Serfice mutasarrıflı̆̆ idare meclisi tarafindan da uygun bulunarak, Ahmed Efendinin berat harc1 olan 300 kuruş ve varaka bahası 40 kuruş olmak üzere toplam 340 kuruşun istihsal edildiği, askerlik işlemleri için redif zabitanından mazbata alındığı ve mahallî ilam-1 şer'î ve mahalle şehadetnamesi ile Evkâf Nezaretine gerekli tevcihin verilmesi için yazı gönderilmişti. ${ }^{[36]}$ Ancak yazının aradan beş ay geçtikten sonra gönderilmesi dikkati çekmektedir. ${ }^{[37]}$

Vakıf gelirine yapılan müdahaleyle ilgili 1889 senesi sonunda hâlen bir işlem yapılmadığı, vakfın muhasebe kayıtlarının gönderilmesinin 1885 ve 1888 senelerinde talep edilmesine rağmen gönderilmediği görülmektedir ki bunun sorumlusu yerel yöneticilerdi. ${ }^{[38]}$ Serfice mutasarrıflığı vakfın 1874-1889 seneleri arasındaki muhasebe işlemlerinin yapılıp koçanlarının hazırlandığı ve 1887/1888 senesi cetveline eklendiğini ifade etse de evkâf muhasebesi söz konusu koçanların henüz hazineye ulaşmadığı nedeniyle "rü’yet olunduğu hikâye olunan" koçanların bir an evvel gönderilmesi için Manastır vilayeti evkâf muhasebeciliğine tahrirat gönderilmesini istemekteydi ki söz konusu tahrirat 14 gün sonra gönderildi. ${ }^{[39]}$ Vakıfla ilgili araştırma yapan Manastır Evkâf Müdürü Rıfat Bey, Kayalar’a gidiş ve dönüş harcırahı olan 90 kuruşu Serfice sancağ "mahallî müteferrika" sütununa işleterek buradan tahsil etmişti. Konuyla ilgili 10 Şubat 1889 tarihli tahriratta ise böyle bir harcırah alabileceğine dair herhangi bir ifade bulunmamaktaydı. Bu tür evkâf-1 mülhakâ muhasebesi yapılırken kimseye bu isimle harcırah verilmediği için söz konusu 90 kuruşun Rıfat Bey'den tahsil edilmesi istenmişti. ${ }^{[40]}$

Vakıf gelirlerine yapılan müdahalenin sona erdirilmesi ve vakıf muhasebe kayıtlarının gönderilmesi hususundaki yazışmalar devam ederken bir başka konu

\footnotetext{
35 BOA, EV. MKT, 1632/66, leff 1, 13 Şaban 1306 (14 Nisan 1889).

36 Aynı Belge, leff 3, 5 Eylül 1305 (17 Eylül 1889).

37 Işlemlerin bu kadar uzun sürmesiyle ilgili olarak Hamadezade Halil Hamdi Paşa 1909 yilında kaleme aldığı layihada vakıf işlemlerindeki muamelatın sade ve basit bir hâle getirilmesine vurgu yapar. Tespitlerine göre basit işlemler bile gereksiz yere uzamaktadır. Öyle ki taşra ile gerçekleşen basit bir yazışma günlerce sürebilmekte ve onlarca yazışma ve müsvedde içerebilmektedir. bk. Ahmet Köksal, "Il. Meşrutiyet Dönemi'nde Vakıfların Yeniden Organizasyonuna Dair Iki Eser: İsmail Sıdkı'nın "Hatırat"ı ve Hamadezade Halil Hamdi Paşa'nın Layihası", Tarih Araştırmaları Dergisi, C. 33, S. 56, Ekim 2014 s. 366.

38 BOA, EV. MKT, 1548/50, 26 Eylül 1305 (8 Ekim 1889).

39 BOA, EV. MKT, 1552/102, 4 Teşrîn-i Sânî 1305 (16 Kasım 1889); BOA, EV. MKT, 1557/99, 18 Teşrîn-i Sânî 1305 (30 Kasım 1889).

40 BOA, EV. MKT, 1580/41, 14 Şubat 1305 (26 Şubat 1890); BOA, EV. MKT, 1582/ 7, 10 Mart 1306 (22 Mart 1890).
} 
vakfın tevliyeti ile ilgiliydi. Konuyla ilgili Serfice mutasarrıflı̆̆ı ve evkâf müdürlüğüne gönderilen bir yazıda ilgili vakfın mütevellileri hakkında verilen bilgide vakfın tevliyeti Derviş İsmail'de iken vefâtı üzerine 21 Kasım 1861 tarihinde Hüseyin Efendi'ye ve onun da vefatı ile 9 Şubat 1887 tarihinde oğlu Mehmed Efendi'ye geçtiği belirtiliyordu. Halihazırda tevliyet Mehmed Efendi'deyken neden İsmail Efendi mahlulüne de veriliyordu. Mehmed Efendi vefât etmişse ehil büyük ve küçük evlâdı yok muydu? Cami halihazırda mevcut mu ve hizmet veriyor mu? gibi sorulara cevap verilmesi istenmekteydi. ${ }^{[4]]}$ Burada asıl dikkati çeken husus, Mehmed Efendi’nin vefatının daha önceden (1887) bilindiği halde tekrar sorulmasıdır. Mehmed Efendi'nin çocuğunun olmadığı başka bir belgede ifade edilerek tevliyetin Osman Nûri Efendìye tevcihinin uygunluğu belirtiliyordu. ${ }^{[42]}$

Caminin müezzinlik ve kayyımlık cihetlerinin Ahmed Efendi'ye verilmesiyle ilgili Serfice idare meclisi mazbatası 17 Eylül 1889 tarihiyle gönderilmişti. Aradan bir seneden fazla zaman geçtikten sonra bu atamayla ilgili Manastır vilayeti ve evkâf muhasebeciliğine gönderilen ilgi yazıda caminin hitabet ve imamet cihetleri günlük 3 akçe ile Yaman Efendi'ye müezzinlik ciheti de günlük 1 akçe ile Seyfeddin Efendi'ye tevcih edildiği ifade ediliyordu. Belgeye göre Hüseyin Bey camisinin kayyımlık ciheti ve Haşim Bey camisinin müezzinlik ve kayyımlık cihetine dair kayıt yoktu. Ayrıca Hüseyin Bey ile Haşim Bey bin Hüseyin Bey camileri ayrı ayrı cami değil ikisi aynı camiydi ve cihetleri elinde bulunduran Yaman ve Seyfeddin Efendiler de vefat etmişlerdi. Kendilerinin ehil çocukları varsa bunların bildirilmesi yazıda ifade edilen bir diğer husustu. ${ }^{[43]} \mathrm{Bu}$ örnekte de görüldüğü gibi merkezle taşra arasında yapılan yazışmalarda ciddî bir gecikme yaşanmaktaydı. Caminin imam ve hatiplik görevine ise 25 Ağustos 1889 tarihinde Hâfız Sâlih Efendi tayin getirilmişti. ${ }^{[44]}$

Vakfın mütevelliliği görevine gelen Osman Nûri daha önce de ifade edildiği gibi yüzbaşı rütbesinde bir askerdi ve Geyve taburunda görev yapmaktaydı. Görevi icabı dışarıda olduğu zaman işleri için vekil olarak tayin ettiği Kayalarlı Bostanc1zâde Süleyman Efendi'yi vakfa kaymakam olarak tayin ederek tevliyetin gerektirdiği işleri yapmak ve gelirlerini almak için "şer ‘̂̀ hüccet" ile görevlendirdi. ${ }^{[45]}$

Osman Nûri Efendi bu arada Evkâf Nezaretine detaylı bir yazı daha kaleme almıştı. İfadesine göre; 1884/1885 yılından beri Hâşim Bey vakfına yapılan müdahaleyle senelik 30.000 kuruştan fazla gelir gasp edilmekteydi. Vakıf hasılatı şartına uygun kullanılmamaktaydı. Buna son verilmesi için açılan davada müdahalenin

\footnotetext{
41 BOA, EV. MKT, 1582/53, 11 Mart 1306 (23 Mart 1890).

42 BOA, EV. MKT, 1626/110, 27 Eylül 1306 (9 Ekim 1890).

43 BOA, EV. MKT, 1634/37, 28 Teşrîn-i Evvel 1306 (9 Kasım 1890).

44 BOA, EV. MKT, 1957/63, 2 Kânûn-ı Sânî 1305 (25 Ağustos 1889).

45 BOA, EV. MKT, 1648/16, 6 Teşrîn-i Sânî 1306 (18 Kasım 1890).
} 
menedilmesine dair Evkâf Nezaretinden mahallî yöneticilere yazı gitmekteydi. 18/21 Mart 1891 tarihlerinde Manastır vilayeti evkaf muhasebeciliğine ve 1 Nisan 1891 tarihinde Serfice Evkâf Müdürlügü̉ne bu yönde emirler gitmişti. Bu emirlerde vakıf gelirlerinin Osman Nûri Efendi'nin oradaki vekiline verilmesinin gerekliliği vurgulanmaktaydı. Ancak gerekli işlemler yapılmadığı için camî-i şerîf ve hayrât-ı sầiresinin harap olduğu ve vakfın son bulmasına çalışıldığını anlayan Osman Nûri Efendi bunun üzerine 1891 Nisan başında Kayalar’a gittiğini ifade eder. Burada, berat, ilam ve emirlere göre hareket edilmesini talep eder. Buna karşın mütegallibe ve nüfuz sahibi olarak nitelendirdiği maarif reisi Cemal Bey ve mahallî idare meclisiyle evkâf müdürünün bir olarak Müslümanlığın şerefini yok sayarcasına vakıf malını paylaştıklarını, muhasebe kayıtlarını gizlediklerine şahit olduğunu ifade eder. Müdâhalenin menedilmesi için Serfice mutasarrıflığı ve evkâf müdürlügüne müteaddid emirler gönderildiği halde hepsi hükümsüz bırakılmıştı. Bunlara verdikleri cevapta da güya evlâd-1 vâkıftan olanlar vakıf gelirlerinin çürümesine neden olduklarından vakıf işlerinin kendileri tarafından idare edilmesine karar verdikleri gibi bütün tamir ve maaş gibi masraflarının da kendisinden tahsil edilmesi şartıyla 11.000 kuruşu maktuen vakfa sarf ettikleri ve geri kalanını da başka tarafa sarf ettiklerini ifade etmeye cüret etmekteydiler. Osman Nûri Efendi, bu ifadelerden sonra vakfın evkâf-1 münderiseden olmadığı, hayrât ve müberrâtının ortada olduğu ve tevliyetinin de evlâd-1 vakfa meşrût bulunduğunu ifade eder. Böyle bir vakfın hasılatının bir evkaf müdür ve kaza idare meclisinin dört yüz senelik teamülü değiştirerek gelirlerini istedikleri gibi taksim etmeye cüret etmelerinin her türlü nizama aykırı olduğunu dile getirir. Bu yapılanlarla ilgili gerekenler aleyhine Şûrâ-yı Devlet'te dava açacağını ifade eden Osman Nûri Efendi dava sonuçlanana kadar vakıf işlerini vekili Halim Efendi’nin idare etmesi hususuyla ilgili Manastır evkâf muhasebeciliğine bir emirnâme yazılmasını ister. ${ }^{[46]}$ Burada evkâf-1 münderise iddiasıyla gelirlerine el konulmak istenen başka vakıfların da bulunduğunu ifade etmek gerekir. Köksal'ın tespit ettiği Şeyh Mecnun'un Horasan kazasında bulunan ve münderise olarak değerlendirilen vakfın aslında mazbut evkaf olduğu ve müdahale edilmemesi yönünde alınan karar buna örnek olarak gösterilebilir. ${ }^{[47]}$

Osman Nûri Efendi’nin daha önce vakıf kaymakamı olarak atadığı Bostanc1başı Süleyman Efendi'nin yerine Halim Efendi'yi kaymakam olarak tayin ettiği görülmektedir. Bu arada Sadaretten Evkâf Nezareti'ne gönderilen bir yazıdan Cemal Bey'in zimmetinde olup aslen vakıf mütevelliliğine ait olan meblağdan 1.000 Osmanlı lirasının Osman Nûri Efendi tarafından askerî bina yapımı için taahhüt edildiği ve kalan 92.000 kuruşun da caminin tamir masraflarına harcanacağına dair dilekçe geldiği ve bu konudaki ilâm ve diğer evrak işlerinin İstanbul'daki vekilleri tarafından takip edildiği ifade edilmekteydi. Bu konuyla ilgili Evkâf Nezaretinin

46 BOA, EV. MKT, 2030/4, leff 2, 5 Eylül 1307 (17 Eylül 1891).

47 Köksal, a.g.e., s. 60-61. 
gerekli çalışmayı yaparak Sadarete bilgi verilmesi istenmekteydi. ${ }^{[48]}$ Osman Nûri Efendi'nin İstanbul'daki vekili olan Haçadur istinaf davası devam ederken vakfa yapılan bu müdahalenin son bulması ve vakıf gelirlerinin usulüne uygun bir şekilde vakıf mütevellisi tarafından idare edilmesi gerekliliğiyle ilgili yazışmalar yapmaktayd1. ${ }^{[49]}$

Askerî binalar için para taahhüt eden Osman Nûri Efendi’nin bu hareketi stratejik miydi yoksa samîmi miydi? bilinmemekle birlikte Devletin üst kademelerinin bu dava üzerine dikkatlerini çekmesini sağladığı bir gerçekti. Sadaretten başka Seraskerlik makamının da bu davaya müdâhil olduğu görülmektedir. Serasker Rıza Paşa 6 Eylül 1892 tarihli yazısında Evkâf Nezaretinden, Cemal Bey’in vakfa yaptığı müdahaleye izin verilmemesi ve vakıf gelirinden vermeyi taahhüt ettiği 100.000 kuruşun gönderilmesini istemekteydi. ${ }^{[50]}$ Evkâf Nezareti’nin Serasker Rıza Paşa’ya cevabında; daha önce hazineye bu yönde şikâyet gelmiş olup Manastır vilayeti ve evkâf muhasebeciliğine 28 Aralık 1890 ve 21 Mart 1892 tarihlerinde durumun ne olduğu sorulmuş; ancak henüz cevap gelmemiş olup Osman Nûri tarafından 25 Haziran 1892 tarihinde Sadarete de tezkire gönderilmişti. Bunun üzerine tekrar mahallî idareden cevap verilmesi istenmiş olup gelecek cevaba göre gereği yapılacakt1. ${ }^{[51]}$ Nihayet Serfice Evkâf Müdürü Rıfat Bey tarafından Evkâf Nezaretine Osman Nûri Efendi'nin Cemal Bey hakkındaki iddialarıyla ilgili detaylı bir cevabî yazı gönderilir. Rıfat Bey yazısında: Kayalar maarif komisyonu reisi olan Cemal Bey'in mutasarrıflıktan aldığı emir üzerine vakfın pazar mahallindeki boş arsası üzerine dükkânlar inşa etmiş ve böylece vakfın yok hükmünde kalan gelirini 15.000 kuruşa çıkartmıştı. Bununla birlikte vatan evlatlarını cehaletten kurtarmak için açılan iptidai mektebinin masraflarına da karşılık bulmuştu. Osman Nûri Efendi’nin iddia ettiği gibi pazar mahallinden elde edilen gelir tevliyete münhasır değildi. Vakfın, Hâşim Bey’in bina ettirdiği caminin imam, hatip ve müezzin maaşları ve caminin tamiri için şart edilmiş olduğu ve mütevelli adına cüzi bir vazife tahsis edildiği berât-1 âlî suretinden anlaşılmaktaydı. İddia edildiği gibi vakfın "evlâdına meşrût" olduğuna dair bir kayıt da bulunmamaktaydı. Caminin görevlileri için verilmesi gereken ücretler şimdiye kadar ödendiği gibi Cemal Bey’in zimmetine geçen herhangi bir para da bulunmamaktaydı. Osman Nûri Efendi görev icabı vakfın başında bulunmadığından vakfın gelirlerini muhafaza etmek için vakıf dükkânları ve diğer gelir getiren akarları usulüne uygun bir şekilde hükûmet-i mahalliye tarafından müzayede ile bir mültezime ihale olunmuştu. Buradan vakfa ait olan kısmı taksit taksit mütevelli vekiline ve maarif hissesi de maarif sandığına verilmekteydi. Eğer Osman Nûri Efendi'nin vekilleri elinde iddia ettiği gibi belge var-

\footnotetext{
48 BOA, EV. MKT, 2030/4, leff 4, 13 Haziran 1308 (25 Haziran 1892).

49 BOA, MF. MKT, 156/114, leff 1-3, 29 Teşrîn-i Evvel 1308 (10 Kasım 1892)-14 Teşrîn-i Sânî 1308 (26 Kasım 1892).

50 BOA, EV. MKT, 1838/10, 25 Ağustos 1308 (6 Eylül 1892).

51 BOA, EV. MKT, 1840/19, 12 Eylül 1308 (24 Eylül 1892).
} 
sa ispat etmek üzere buraya getirmesi gerekmekteydi. ${ }^{[52]}$ Rifat Bey'in ifadelerinde vakfın evlatlık vakıf olup olmadığının bilinmediği, vakfiyesinin bulunmadığından durumun anlaşılamadığg ${ }^{[53]}$, Osman Nûri Efendi’nin iddialarının tamamının asılsız olduğu ve asıl kendisinin vakfı zarara uğrattığı, Cemal Bey'in mutasarrıflık emriyle bu işlemleri yaptığı ve zimmetine para geçirmediği ifade ediliyordu ki önceden gönderilen ve 75.000 kuruşun zimmete geçirildiğini ifade eden yazılara tamamen ters düşüyordu. Manastır Vilayeti Valisi Mehmed Faik tarafından Sadarete gönderilen bir yazıda Cemal Bey'in zimmetinde para olmadığı, Osman Nûri Efendi’nin askerlik vazifesi nedeniyle yerinde bulunmamasından dolayı vakıf gelirlerini idare etmek üzere mültezime verildiği ve masraflar haricinde vakıf geliri olarak 20.000 kuruş olduğu ve bu paranın 4.850 kuruşunun mütevelli ve kalanının mültezimler zimmetinde olduğu ifade edilmekteydi. Osman Nûri Efendi'nin okul gelirine müdahale etmeye hakkının olmadığ istediği yere harcamaya yetkili olduğu da belirtilmekteydi. ${ }^{[54]}$

Rıfat Bey ve Mehmed Faik'in bu yazdıklarına karşın Evkâf Nezareti İdare Meclisi farklı düşünmekteydi. Meclis bu konudaki kararını şu ifadelerle dile getirmekteydi: Hazinenin emri olmaksızın maarife evkaftan gelir temin ettikleri için mahalli evkaf muhasebecisi ve müdürüne uyarılmalıdır. Yine evkaf hazinesinin resmî izni olmadan ilgili arsaya Cemal Bey’in zoruyla bina inşa edildiği için arsa ve üzerinde inşa edilenlerin vakıf nam ve hesabına idare olunması lazım geleceği meclis tarafından kabul edilmiştir. Bunun için arsa üzerine yapılan binalardan maarife aktarılan meblağ mahalli evkaf muhasebeciliğinden istenilmesinin mahalli maarif müdürlüğüne yazılması için Maarif Nezaretine de ayrıca tezkire yazılmalı ve tüm süreç sadarete bildirilmelidir. ${ }^{[55]} \mathrm{Bu}$ yazışmalar arasında Osman Nûri Efendi Sadarete 13 Nisan 1893 tarihinde bir dilekçe daha yazmıştı. Bu dilekçesinde vakfa gelir getiren dükkânlarla ilgili yeni bilgiler vermekteydi. Buna göre vakfa ait hafta pazarının yanındaki arsa üzerinde 200 adet ahşap dükkân bulunmaktayd..$^{[56]} \mathrm{Bu}$ arada 25 Haziran 1892 tarihli Sadaret yazısına Evkâf Nazırı Gâlib Paşa tarafından 19 Ağustos 1893 tarihinde verilen cevapta da vakfa gelir getiren akarlara maarif tarafından müdahale edilmemesi ve okul için para ayrılması gibi bir hususa gidilmemesi gerektiği ifade ediliyordu. ${ }^{[57]}$

52 BOA, EV. MKT, 2030/4, leff 7, 21 Teşrîn-i Evvel 1308 (2 Kasım 1892).

53 Vakfiye günümüzde bir arşiv tasnifinde bulunamamıştı. Ancak söz konusu dönemde vakfiyenin mütevelliler tarafından dahi elde edilememiş olması farklı bir yorumda bulunulmasını sağlayabilir. Mahkemelerde tanzim edilen vakfiyeler sicile işlendiği gibi bir nüshası da vâkıfın elinde bulunuyordu. 1826'da Evkâf-ı Hümayun Nezareti'nin kurulmasıyla mütevelliler ve nazırların ellerindeki vakfiyeler toplanarak VGMA'daki vakfiye defterlerine kaydedildi. Vakfiye defterlerindeki bu istinsah kayıtlarda da bahsi geçen vakfiyenin bulunamaması vakfiyenin daha eski bir tarihte zayi olduğunu düşündürebilir.

54 BOA, BEO, 194/14518, leff 3, 27 Mayıs 1309 (8 Haziran 1893).

55 BOA, EV. MKT, 2030/4, leff 7, 21 Haziran 1309 (3 Temmuz 1893).

56 BOA, BEO, 194/14518, leff 2, 13 Nisan 1309 (25 Nisan 1893).

57 BOA, BEO, 25/1830, leff 2, 7 Ağustos 1309 (19 Ağustos 1893). 
Yazışmalardan ortaya çıkan sonuç; Cemal Bey'in zimmetine herhangi bir para geçirmediği, buna karşın vakfın akarından maarife para ayrılmasının da usule aykırı olduğu ve gelirin idaresinin mütevelli ya da vekiline bırakılması gerektiğidir. Burada Serfice Evkâf Müdürü olan Hasan Basri Bey’in 1 Temmuz 1887 tarihli ve vakıf gelirinden 75.000 kuruşun Cemal Bey tarafından zimmetine geçirildiğiyle ilgili yazısını unutmamak gerekir. Tüm bu yazışmalardan sonra vakıf ve akarıyla ilgili yapılması gerekenler ortaya konulmuşsa da Kayalar kaymakamı tarafından dükkânların bir kısmının gelirinin ayrılarak eğitime verilmesi noktasında baskı yapmaktaydı. Vakfın mütevelli vekili Halim ve vakıf ailesinden Seyfeddin ve Şuayip bu noktadaki şikâyetlerini telgrafla Manastır vilayetine bildirmişlerdi. ${ }^{[58]} \mathrm{Bu}$ şikâyet konusunun bir an önce halledilmesi için Sadaretten ve Dahiliye Nezareti mektubi kaleminden Manastır vilayetine 8 ve 12 Aralık 1894 tarihlerinde yazılar gönderilmişti. ${ }^{[59]} \mathrm{Bu}$ arada Osman Nûri Efendi’nin Dahiliye Nezaretine Kayalar kasabasında Hâşim Bey Camii yakınında kurulan pazarın yerinin başka yere nakledildiğini ifade eden bir yazı gönderdiği görülmektedir ki ${ }^{[60]}$ burada vakıf mütevellisinin hakkını araması karşısında yerel yöneticilerin pazarın yerini değiştirmek gibi vakfı zarara uğratacak bir girişimde bulundukları anlaşılmaktadır.

Vakfa gelir getiren pazar mahallindeki arsa üzerinde mevcut dükkânlar üzerinde 1894 senesi sonunda yeni bir tartışmanın başladığı görülmektedir. Söz konusu tartışma maarife ait olmak üzere inşa edilen dükkânların aslında "arsa-i hâliye" yani boş arsa üzerine yapıldığı iddiasıdır. Evkâf Nazırı Galib Paşa tarafından Maarif Nezaretine gönderilen ilgi yazıda söz konusu boş arsanın vakıf arsası ile sınır olduğundan karıştırıldığını ifade ederken bu konuda herhangi bir şüphe kalmaması adına mahallî evkâf muhâsebecisi, maarif müdürü ve ilgili diğer kişilerin bulundukları bir ekip tarafından bir harita düzenlenmesini istemektedir. ${ }^{[61]}$ Osman Nûri Efendi ise Cemal Bey’in zimmetine para geçirdiği yönündeki iddialarını devam ettirmekteydi. Osman Nûri Efendi 21 Ocak 1895 tarihinde Evkâf Nezaretine gönderdiği yazıda süreci kısaca tekrar hatırlattıktan sonra Cemal Bey’le ilgili; günlük dört akçe alan ve vâkıf evladından olan mütevelli tarafından idare edilmekte olan vakıf gelirleri, Rumi 1300 yılında kendisine maarif reisi unvanını veren ve aslında orada maarif reisi olarak tanınmadığ libe" Cemal Bey söz konusu vakfı mahvettiği gibi gelirini de kendisine yemeklik yapmak için gerçeğe aykırı ve haksız yere vakfa müdahale etmekteydi ifadelerini kullanır. Vakfa yapılan müdahale hakkında Evkâf Nezareti idare meclisi kendilerinin lehine karar vermiş ve bu karar, 19 Ağustos 1893 tarihinde Manastır evkaf muhasebeciliğine iletilmişti. Vakfın geliri on seneden beri Kayalar idare meclisinin

\footnotetext{
58 BOA, EV. MKT, 2108/123, 4 Ağustos 1310 (16 Ağustos 1894).

59 BOA, BEO, 530/39685, 26 Teşrîn-i Sânî 1310 (8 Aralık 1894); BOA, DH.MKT, 317/69, 30 Teşrîn-i Sânî 1310 (12 Aralık 1894).

60 BOA, DH. MKT, 268/15, 24 Temmuz 1310 (5 Ağustos 1894).

61 BOA, MF. MKT, 237/58, leff 1, 27 Ağustos 1310 (8 Eylül 1894).
} 
bir alakası olmadan bir mazbatayla her sene 30.000 kuruş bedelle mültezime ihale edilmekte ve açıktan açı̆̆a Cemal Bey eline geçmekteydi. Cemal Bey'in zimmetine 200.000 kuruş para geçirdiği vakıf hasılatı muhasebesinin yerinde "ma'rifet-i şer 'le" yapıldı̆̆ı ve "dünyevî ve uhrevî" mesuliyet sahibi olmamak adına bunu engellemek için bu müracaatı yaptığını bildirir. ${ }^{[62]}$ Tüm bu gelişmeler esnasında cami tamire muhtaç duruma gelmişti. Bu minvalde caminin hesaplarında yeterli para olduğu keşfinin ve münakasasının yapılıp gönderilmesi Evkâf Nezaretinden Manastır Vilayeti Evkaf Muhasebeciliği'ne bildirilmişti. ${ }^{[63]}$

Yaptığı girişimlerden istediği sonucu alamayan Osman Nûri Efendi, çözümü tekrar Sadarete başvurmakta bulur. Bu talebi yinelemesinin sebebi, vakfa vekil olarak bıraktığı Halim Efendi’nin 10 Nisan 1895 tarihinde gönderdiği telgraftır. Hâlim Efendi kısa telgrafında şunları söylemekteydi: Maarif Reisi Cemal Bey’in sülalenize yaptıklarından menedilmesi mümkün değildir. Bundan sonra iş daha kötü yere varabilir. Yaptığım müracaatlara hükûmet önem vermiyor. Vebali sebep olanlara ait olmak üzere görevimi başka birisine tevdî etmeniz gerekmektedir. ${ }^{[64]}$ Halim Efendi bu ifadelerle görevinden istifa etmişti. Osman Nûri Efendi bu yazısında mütevellisi olduğu vakfın gelirini kendi mâlikânesi gibi addederek kendisine "me'kel" edinen Kayalarlı Cemal Bey’in bu yaptıklarına kaza kaymakamının da iştirâk ettiğini ifade eder. Bu nedenle olayı Sadarete bildirmek zorunda kaldığını ifade eden, maalesef buradan da bir sonuç alamadığını, artık bu uğurda harcayacak parasının da kalmadığını belirten Osman Nûri Efendi vekili Hâlim Efendi’nin belki de vakfın hukukunu korumaya çalışırken hayatının tehlikeye girdiğine kanaat ettiği için istifasını bardağ 1 taşıran damla olarak görür. Bu talebinin son olduğunu yazan mütevelli "etyâm ve evkâfın mededgâh-1 yegânesinden tedâbir-i mü'essire-i kat'iyye ittihâzıyla hukûk-1 vakfın ayâdı mütegallibe ve cebâbireden tahlîsi bi-hasbü’t-tevliye kemâl-i tazarru 'la niyaz ve istirhâm eylerim" ifadeleriyle yazısına son verir. ${ }^{[65]}$ İlgili belgede kısa süre içinde konuyla ilgili yapılan yazışmalar tablo olarak gösterilmiştir ki işin ne derece sürüncemede kaldığı, verilen kararlara rağmen uygulamada sıkıntılar yaşandığını göstermesi açısından aşağıda verilmektedir.

\footnotetext{
62 BOA, EV. MKT, 2235/13, 9 Kânûn-ı Sânî 1310 (21 Ocak 1895).

63 BOA, EV. MKT, 2068/79, 28 Kânûn-ı Sânî 1310 (9 Şubat 1895).

64 BOA, BEO, 429/32115, leff 3, 29 Mart 1311 (10 Nisan 1895).

65 Aynı Belge, leff 2, 2 Nisan 1311 (14 Nisan 1895).
} 


\begin{tabular}{|c|c|c|c|}
\hline $\begin{array}{l}\text { Aded-i } \\
\text { Numro }\end{array}$ & Tarihi & $\begin{array}{l}\text { Emirnâme-i Şeref- } \\
\text { tastîr Buyurulan } \\
\text { Makâmât-ı Aliyye }\end{array}$ & Makâmât \\
\hline 18 & 20 Haziran 1310 & Sadâret-i Uzmâdan & $\begin{array}{c}\text { Manastır Vilâyet-i Celîlesine } \\
\text { Tahrîrât-1 Sâmiye }\end{array}$ \\
\hline 1051 & 2 Ağustos 1309 & Sadâret-i Uzmâdan & $\begin{array}{c}\text { Ma'ârif Nezâret-i Celîlesine } \\
\text { Tezkire-i Sâmiye }\end{array}$ \\
\hline 5801 & $\begin{array}{c}19 \text { Teşrîn-i Sânî } \\
1310\end{array}$ & Sadâret-i Uzmâdan & $\begin{array}{c}\text { Manastır Vilâyet-i Celîlesine } \\
\text { Tahrîrât-1 Sâmiye }\end{array}$ \\
\hline 105 & $\begin{array}{c}22 \text { Teşrîn-i Sânî } \\
1309\end{array}$ & $\begin{array}{l}\text { Cânib-i Celîl-i Meşî- } \\
\text { hatpenâhîden }\end{array}$ & $\begin{array}{l}\text { Serfice Mutasarrıflığına } \\
\text { Tahrîrât-1 Aliyye }\end{array}$ \\
\hline 222 & $\begin{array}{c}30 \text { Teşrîn-i Sânî } \\
1310\end{array}$ & $\begin{array}{l}\text { Dâhiliye Nezâret-i } \\
\text { Celîlesinden }\end{array}$ & $\begin{array}{c}\text { Manastır Vilâyet-i Celîlesine } \\
\text { Tahrîrât-1 Aliyye }\end{array}$ \\
\hline 78 & $\begin{array}{l}24 \text { Şa‘ban } 1310 \\
\text { ve } 24 \text { Kânûn-1 } \\
\text { Evvel } 1304\end{array}$ & $\begin{array}{l}\text { Dâhiliye Nezâret-i } \\
\text { Celîlesinden }\end{array}$ & $\begin{array}{l}\text { Serfice Mutasarrıflığına } \\
\text { Tahrîrât-1 Aliyye }\end{array}$ \\
\hline 509 & $\begin{array}{c}19 \text { Teşrîn-i Sânî } \\
1308\end{array}$ & $\begin{array}{l}\text { Adliye Umûr-1 Hukû- } \\
\text { kiyeden }\end{array}$ & $\begin{array}{l}\text { Manastır İstinaf Müdde ‘̂̀-i } \\
\text { Umûmîliğine Tahrîrât }\end{array}$ \\
\hline 0 & 3 Ağustos 1309 & $\begin{array}{l}\text { Adliye Nezâret-i Celî- } \\
\text { lesinden }\end{array}$ & $\begin{array}{l}\text { Te’kîden Manastır İstinaf } \\
\text { Müdde‘î-i Umûmîliğine } \\
\text { Tahrîrât-1 Aliyye }\end{array}$ \\
\hline 19 & 7 Ağustos 1309 & $\begin{array}{l}\text { Evkâf-1 Hümâyûn } \\
\text { Nezâret-i Celîlesinden }\end{array}$ & $\begin{array}{c}\text { Ma'ârif Nezâret-i Celîlesine } \\
\text { Tezkire-i Sâmiye }\end{array}$ \\
\hline 28 & 7 Ağustos 1309 & $\begin{array}{l}\text { Evkâf-1 Hümâyûn } \\
\text { Nezâret-i Celîlesinden }\end{array}$ & $\begin{array}{c}\text { Manastır Evkaf Muhasebeci- } \\
\text { liğine ve Serfice Müdürlüğü- } \\
\text { ne Tahrîrât-1 Aliyye }\end{array}$ \\
\hline 320 & $\begin{array}{l}11 \text { Saferül-hayr } \\
1311\end{array}$ & $\begin{array}{l}\text { Evkâf-1 Hümâyûn } \\
\text { Nezâret-i Celîlesinden }\end{array}$ & $\begin{array}{c}\text { Makâm-1 Sadâret-i Uzmâya } \\
\text { Tezkire }\end{array}$ \\
\hline 20 & 29 Ağustos 1310 & $\begin{array}{c}\text { Evkâf-1 Hümâyûn } \\
\text { Nezâret-i Celîlesinden }\end{array}$ & $\begin{array}{c}\text { Manastır Vilâyet-i Celîlesine } \\
\text { Tahrîrât Yazılmışdır }\end{array}$ \\
\hline 37 & 29 Ağustos 1310 & $\begin{array}{c}\text { Evkâf-ı Hümâyûn } \\
\text { Nezâret-i Celîlesinden }\end{array}$ & $\begin{array}{l}\text { Manastır Evkâf Muhâsebeci- } \\
\text { liğine Tahrîrât-1 Aliyye }\end{array}$ \\
\hline
\end{tabular}

Tablo 2: Hâşim Bey vakfına yapılan müdahalelerle ilgili yapılan yazışmalardan bir kısmı. ${ }^{[66]}$

Osman Nûri Efendi gerçekten de bundan sonra konuyla ilgili herhangi bir makama talepte bulunmamıştı. Cumhurbaşkanlığı Osmanlı ve Vakıflar Genel

66 Aynı Belge, leff 4. 
Müdürlügü arşivlerinde yapılan taramada aksini ortaya çıkaracak bir belgeye rastlanmadı. Bununla birlikte Manastır Valisi Abdülkerim Paşa tarafından Evkâf Nezaretine gönderilen bir yazıda tarafların bir araya geldiği görülmektedir. Serfice sancağı evkâf müdürü ve vakıf mütevellisi Osman Nûri Efendi vilayet meclisinde vakıf hakkındaki iddialarını dile getirirler. Evkaf müdürünün de olduğu sırada Osman Nûri Efendi'nin meclise gösterdiği senette vakfın Hâşim Bey adına mevcut olduğu "musakkafât ve müstegallâtı" eskiden beri Haşim Bey Camiìnin imam, hatip, müezzin maaşları ve tamirine, bir de caminin yakınında olup "vâkıf-1 mûmâ-ileyhin müberrâtından" bulunan sıbyan mektebi öğretmenlerinin maaşı ve masraflarına şart edilmişti. Söz konusu mektep zamanında küçük yapıldığı ve şu anda ihtiyaca cevap veremediğinden beklenen eğitimi verememekteydi. İhtiyaca cevap veremeyen bu okul yerine vakıf gelirinden para ayrılan yeni okul belirlenmişti. Okulun masrafları vakıf gelirinden karşılanmak üzere düzenlenen evrakta görüldüğü gibi öğretmen ve kapıcı maaşlarıyla diğer masraflarına karşılık olmak üzere aylık 708 kuruş 10 paradan senelik 8.500 kuruş tutmaktaydı. Bu para her ay taksitle vakıf gelirinden alınacak olup mütevellinin rızası olduğu görülmekteydi. Vakıf mütevellisinden okul için bundan başka bir para talep edilmemesi kararlaştırılarak gereğinin yapılması Serfice mutasarrıflı̆̆ına tebliğ edilmişti. ${ }^{[67]}$ Burada dikkati çeken husus, daha önce vakfın hayrâtından olarak bahsi hiç geçmeyen bir sıbyan mektebinin bulunduğu bilgisidir ki burası yeterli gelmediği için yerine iptidai mektebinin masraflarının vakıftan karşılanması Osman Nûri Efendi tarafından taahhüt edilmişti. Osman Nûri Efendi’nin bu taahhüdü isteyerek mi yoksa istemeden mi verdiğini bilmek eldeki verilere göre mümkün olmasa da yapılmak istenen bu işin mümkün olmadığı kısa süre sonra ortaya çıkacaktı. Vakfın hayrâtı arasında sıbyan mektebi olduğu sadece burada ifade edilse de Kayalar'da Hâş̧im Bey iptidai mektebi olduğu bir imtihan cetvelindeki "Hâşim Bey Câmii’nin Hasanoba Mekteb-i İbtidầ îsi” ibaresinden anlaşılmaktadır. ${ }^{[68]}$

Hatırlanacağ üzere Serfice Evkâf Müdürü Rıfat Bey 1893 yılında Cemal Bey’in zimmetine para geçirmediği yönünde bir yazı kaleme almıştı. Aradan üç sene geçtikten sonra aynı Rifat Bey bu defa farklı tespitlerde bulunuyordu. Rifat Bey merkezden gelen emirle yapılan inceleme sonucunda; Cemal Bey'in vakıf gelirlerinden vakfa harcanan para haricinde zimmetinde 178.000 kuruşun kaldığı Kayalar şer ‘̂̀ mahkemesi tarafından tespit edilmişti. Ancak kaza nâibi bu paranın tazmin edilmesi hükmünü ertelemekteydi. Bu tavır hem hukuka uygun değildi hem de vakfın zararınaydı. Cemal Bey'in zimmetinde olan para bir an evvel alınmalıyd $1 .{ }^{[69]}$ Evkâf Nezareti mektubi kalemi Kayalar naibinin hükmü ertelemesiyle ilgili; vakfın hukukunu korumak hükûmetin aslî görevi olduğundan söz konusu naibin bu hareketine kayıtsız kalınmaması gerekmektedir. Bununla ilgili olarak vakıf hukukunun

67 BOA, EV. MKT, 2142/113, 25 Teşrîn-i Evvel 1311 (6 Kasım 1895).

68 BOA, MF. İBT, 20/34, 17 Kânûn-ı Evvel 1324 (30 Aralık 1908).

69 BOA, EV. MKT, 2235/13, 10 Kânûn-ı Sânî 1311 (22 Ocak 1896). 
muhafazası adına muhasebesinin yapılması ve ilgili evrakın gönderilmesi için liva mutasarrıflı̆̆ıla evkaf müdürlüğüne tebligat yazılmalıdır tespitlerini yapmaktay$\mathrm{d}_{1}{ }^{[70]}$

Vakıf gelirlerine maarif tarafından yapılan müdahaleyle ilgili her ne kadar daha önce Manastır idare meclisinde iptidai mektebi için senede 8.500 kuruş verilmesi mütevelli Osman Nûri Efendi tarafından taahhüt edilmişse de Manastır valisi Abdülkerim Paşa’nın Dahiliye Nezaretine gönderdiği 1 Mayıs 1898 tarihli yazıda vakfın tevliyeti evlâdına meşrût olup sadaka tevliyeti olmadığından mütevellinin taahhüdünü yerine getirmediği ve okulun geri kaldığı ifade edilmişti. Dahiliye Nezareti de durumu Sadarete bildirerek 10 aydan beri kapalı olan okulun açılması için masraflarına karşılık olarak çarşamba günleri kurulan pazarda sergi açanlarda 5-10 ve 20 para vergi alınması, eski pazar yerine 10 dakika uzaklıkta Cemal ve Zülfikar Beylerin hibe ettiği 5 dönüm 1,5 evlek arazi üzerine 3-4 baraka inşa edilmesi ve cumartesi günleri de bir pazar kurulup bu pazardan da vergi alınması teklif edilmişti. Buradan elde edilecek gelirlerden yerine konulmak üzere belediye gelirinden 2000-3000 kuruşun okul için hemen aktarılmak istenmesi de talepler arasındaydı. Bu teklifler merkez tarafindan kabul edildi ve iradesi 30 Ekim 1898 tarihinde çıktı. ${ }^{[71]}$

Vakfın gelirleri ile ilgili problem bu şekilde çözülmüştü; ama vakfın yönetimi ile ilgili bir karışıklık yaşanmaktaydı. Mütevelli Osman Nûri Efendi’nin büyük oğlu Ragıb Bey babasının vefatı üzerine tevliyetin kendisine intikal ettiğini Kayalar şer ' $\hat{i}$ mahkemesinden i'lâm hazırlandığı ve kaza meclis idaresi tarafından 27 Mart 1902 tarihli ve 8 numaralı mazbata ile durumun Serfice mutasarrıflı̆̆ına bildirildiğini ifade ediyordu. Serfice'de ilgi evrakın incelemesi yapılarak evkâf müdüriyetine havale edilmişti. Ancak aradan geçen yaklaşı üç aya rağmen evraklar Evkâf Nezaretine gönderilmeyerek Serfice evkâf müdürü tarafından tutuluyordu. Evrakı neden göndermediği anlaşılmamakla birlikte bu türden evrakın bir an evvel ilgili makama gönderilmesi usule uygun olduğundan konuyla ilgili işlemlerin İstanbul tarafından yapılabilmesi için ilgili i'lâm ve mazbatanın bir an önce gönderilmesi talep edilmekteydi. ${ }^{[72]} \mathrm{Bu}$ isteğe evkâf müdüriyetinden verilen cevapta; söz konusu tevliyet Ragıb Bey’e verilmiş olsa da vakfın vakfiyesi olmadığ gibi Osman Efendi'nin başka küçük çocukları da olduğu anlaşıldığından, vakfiyesi olmayan ve mahkeme-i şer'iyye sicillâtında bulunmayan tevliyetler için kadîme riayet olunmaması gerektiği Evkâf Nezaretinden kendilerine iletildiğinden bu işlemin uygun görülmeyerek bekletildiği ifade edilmişti. ${ }^{[73]}$ Evkâf Nezareti mektubî kalemi konuyla ilgili 3 Nisan 1905 tarihli Serfice mutasarrıflığı ve evkâf müdürlügüne gönderdiği

\footnotetext{
70 BOA, EV. MKT, 2237/94, 11 Teşrîn-i Sânî 1312 (23 Kasım 1896).

71 BOA, Irade Maarif (i. MF), 5/22, 18 Teşrîn-i Evvel 1314 (30 Ekim 1898).

72 BOA, EV. MKT, 2270/115, leff 1, 6 Haziran 1318 (19 Haziran 1902).

73 Aynı Belge, leff 2, 6 Ağustos 1318 (19 Ağustos 1902).
} 
yazıda; harbiye mektebi öğrencisi olan Ragıb Bey’in vakfın tevliyetinin kendisine verilmesi ile ilgili talebi karşısında evkâf müdürlügü 8 Ocak 1903 tarihli bir yazı kaleme aldığını belirtir. Bu şukkada Ragıb Bey’in harbiye mektebi öğrencisi olduğu ve tahsiline devam ettiğinden vakıf işlerini yürütemeyeceği, kendisinin iki kardeşi daha olduğu ve tevliyetin bu iki kardeşe müşterek olarak tevcîhi gerekirken Ragıb Bey’e tevcihinin uygun olmayacağı dile getirilmektedir. Çok ilginçtir ki yazının devamında Hâşim Bey Vakfı'nın tevliyetinin Mehmed Efendi'nin vefâtıyla oğlu Halil Efendi'ye verilmesi gerekirken bilâ-veled vefat etti denilerek Osman Nûri Efendi'ye tevcih edildiği hâlbuki Halil Efendi'nin şu anda hayatta olduğu ve tevliyetin kendisine verilmesini istediği ifade edilmektedir. Tüm bu nedenle tevliyetin Ragıb Bey’e verilmesinde tereddüt yaşanmaktaydı. Bu nedenle tevliyetin kime verileceğiyle ilgili gerekli tahkikat yapılmalı ve neticesine göre hareket edilmeliydi. ${ }^{[7]}$ Serfice mutasarrıflı̆̆ bu tereddütler karşısında tevliyetin Ragıb Bey’e tevcîhine dair evrakla birlikte Evkâf Nezaretine gönderilmek üzere i'lâm-1 şer 'î mazbata ile Manastır vilayetine takdim edilmiş ve konuyla ilgili karar verilene kadar tevliyet cihetine başkasının müdahale etmemesi Cuma kaymakamlığına tebliğ etmişti. ${ }^{[75]}$

$\mathrm{Bu}$ yazışmalardan Mehmed Efendi'nin yok denilen ama var olan oğlu Halil Efendi'nin 20 Aralık 1902 tarihinde daha önceden hakkını yedikleri ve tevliyetin kendisine iadesi için talepte bulunduğu görülmektedir. ${ }^{[76]}$ Vakfın mütevelliliği noktasında yaşanan bu ihtilaf esnasında Ragıb Bey okulu bitirmiş ve Siroz'da Mülâzım-1 Evvel olarak görev yapmaktaydı. Buradan, Rumeli Müfettişi Hüseyin Hilmi Paşaya konuyla ilgili gönderdiği yazıda Mart 1902 tarihinde vakfın tevliyetinin ilam ve mazbata alarak kendisine geçtiği; ancak evrakların Serfice evkâf müdüriyetinde tutulduğunu ifade eder. Talebi üzerine evrak Manastır muhasebeciliği tarafından istenmişse de teamül-ü kadîmi ispat edilemediğinden yeniden ilâm alınması istenir. Kasım 1903'te yeni bir "i'lâm-1 şer'î" alır ve Serfice mutasarrıflı̆̆ına takdim eder. Serfice Evkâf Müdürü bu kez de nedeni anlaşılamayan bir nedenle yine evrakı işlem görmesi için göndermeyerek kendisinde tutar. İlgili tevliyet babası Osman Nûri Efendi’nin beratından istihsâl ettiği bilgisi "sû-i taksîr” ile evlâd- 1 vâkıfdan Mehmed ile evlâd-1 evlâd-1 evlâd-1 vâkıfdan Osman Nûri kardeş addedilerek kendisine amcasının oğlunun hayatta olduğundan tevliyetin amcasının oğlunda olması gerektiği ifade edilir. Ragıb Bey'in mesleği icabı orada olmamasını fırsat bilen evkâf müdürü, tevliyetin amcasının oğluna verilmesinin uygun olduğunu belirtip Kayalar kaymakamlığına da bu yönde emir yazdırır ve bu Ragıb Bey tarafından duyulur. Ragıb Bey'in gerek elindeki berat ve iki adet ilamla ve gerekse teamül gereği hakkı olmasına rağmen söz konusu müdür yetkisi dışında tevcih evrakını kendisinde tutmakta ve vakıf şartına aykırı olarak başkasına tevcih etmektedir. Bu hem kanuna hem de padişahın adaletine aykırıdır. Ragıb Bey bu

74 BOA, EV. MKT, 2971/121, 21 Mart 1321 (3 Nisan 1905).

75 BOA, EV. MKT, 3119/40, leff 1, 11 Haziran 1322 (24 Haziran 1906).

76 Aynı Belge, leff 2, 26 Kânûn-ı Evvel 1318 (8 Ocak 1903). 
nedenle ilgili evrakın müdürün elinden alınarak yeni bir berat verilmesi ve adı geçen vakfın idaresinin Kayalar'daki vekiline verilmesi hakkında gereken yerlere emir verilerek hukukunun korunmasını istemektedir. ${ }^{[7]}$ Hüseyin Hilmi Paşa, belgenin arka sayfasına: Serfice Evkâf Müdürü böyle bir şeye cüret ettiyse ve doğruysa azli gerekir. Durum acilen araştırılıp neticesi bildirilsin notunu düşerek Manastır Evkâf Muhasebeciliği'nden bilgi ister. Manastır evkâf muhasebecisi Faik Bey bu isteğe verdiği cevapta teamül-ü kadîm hakkında Cuma şer'î mahkemesi tarafından düzenlenen ilâmın usulsüz olduğu ve usule uygun olarak iade olunduğu ifade edilerek henüz tekrar düzenlenip Serfice’ye gelmediği ifade edilmekteydi. Cuma kazasında kalan evrakın buldurulup gereğinin bir an evvel yapılması da evkâf müdürüne sıkıca tembih edilmiști. ${ }^{[7]}$ Aslında tevcih evrakı 19 Mart 1903 tarih ve 45 numaralı tahrirat ile vilâyete gönderilmişti. Bu nedenle tevcih evrakının hazineye gönderilmesi gerekliliği Evkâf Nezareti Mektûbî Kalemi’nden Manastır Vilayeti’ne ve vilayet evkâf muhasebeciliğine bildiriliyordu. ${ }^{[79]}$

Haşim Bey vakfına yapılan usulsüz müdahaleler, tevliyet tartışmaları arasında cami ve vakfa gelir getiren dükkânlar tamire muhtaç duruma gelmişti. Yapılan incelemede gerekli tamiratın 2.717 kuruş masrafla yapılacağı anlaşılmış olup keşif defteri düzenlenmişti. Tamiratın inşaat mevsimi geçmeden bir an önce yapılması istenmekteydi. ${ }^{[80]}$ Ancak tamiratla ilgili sunulan keşif defterinin "muvâfik-1 fen" olmadığı, yapılan incelemede anlaşıldığından fen memurları tarafından düzenlenen rapora göre yeni bir keşif defterinin hazırlanarak gönderilmesi ve tamir masraflarının nereden ve ne şekilde karşılanacağının da bildirilmesi gerekmekteydi. ${ }^{[81]}$

Gerek Cumhurbaşkanlığı Osmanlı Arşivi gerekse Vakıflar Genel Müdürlüğü arşivinden konuyla ilgili tespit edilebilen son belge 30 Mayıs 1909 tarihli olup vakfın işleyişi ile ilgili son derece önemli bilgiler vermektedir. Buna göre Hâşim Bey vakfı mütevellisinin elinde berât olmadığını ifade eden Serfice evkâf müdürü Es-Seyyid Ahmed Efendi, beratı olmayan mütevellinin cami akarının tamiri için bir senede 13.000 kuruş harcadığını belirtir. Mütevelli bu paranın tazmîni ve vakfın eski usulüne geri döndürülerek söz konusu evkâfa başka kimsenin müdahale ettirilmeyip evkâf idâresi tarafından gelirlerin idare edilmesini istemekteydi. Konuyla ilgili yapılan yazışmalardan vakfın gelirlerinin mahallî meclis idaresi ve belediye tarafından idare edildiği anlaşılmaktaydı. Es-Seyyid Ahmed Efendi vakfın evkâf idaresi tarafından yönetilmesi gerektiğine dair mutasarrıflı̆̆a bir yazı kaleme alır. Kaza kaymakamlığ 1 cevabında vilayet umumi meclisinin mazbatası ile vakfın hâkim-i şer‘î başkanlığından teşekkül eden komisyon tarafından idare edildiği ve

\footnotetext{
77 BOA, Teftişat-ı Rumeli Evrakı Arzuhaller (TFR. I. ŞKT), 87/8656, 19 Nisan 1322 (2 Mayıs 1906).

78 Aynı belge.

79 BOA, EV. MKT, 3121/85, 13 Mart 1323 (26 Mart 1907).

80 BOA, EV. MKT, 3265/113, 11 Teşrîn-i Sânî 1324 (24 Kasım 1908).

81 BOA, EV. MKT, 3270/250, 6 Kânûn-ı Sânî 1324 (19 Ocak 1909).
} 
hilâf-1 şart-1 vâkıfa iptidai mektebi öğretmen ve diğer görevlilere senelik 8.500 kuruş vakıf gelirinden verildiği ve gerek gelirin toplanması gerekse okul için para harcanmasının uygun olduğu Serfice Livası İdare Meclisi tarafından tasdik edilmişti. Dolayısıyla gerek vakıf gelirinin idaresi gerekse okula para harcanması "nizâmât-1 mevzû‘a ve evâmir-i aliyyeye külliyen muhâlif” olduğundan konuyla ilgili gerekenin bir an evvel yapılması istenmekteydi. ${ }^{[82]}$

Günümüzde Kayalar'da Osmanlı Devleti döneminden hükûmet konağı haricinde herhangi bir eser bulunmamaktadır. ${ }^{[83]}$ Haşim Bey camisi de Kayalar’ın elden çıkmasından sonra yıkılmıştı. Ne zaman yıkıldığı ise tam olarak bilinmemektedir. Cumhurbaşkanlığı Cumhuriyet Arşivi’nde Kayalar merkezi olan Cuma’nın tasfiye talepnamesinde dört adet cami bulunmaktadır. Bu camiler; Yukarı Mahalle, Orta Mahalle, Aşağı Mahalle ve Pazar camileridir. Hâşim Bey camisinden bahsedilmemekle birlikte caminin pazar mahallinde olduğu göz önüne alındığında $\mathrm{Pa}$ zar Camii olarak isimlendirilen cami ile aynı olması ihtimal dahilindedir. ${ }^{[84]}$

\section{SONUÇ}

Osmanlı Devleti tarih sahnesinde bulunduğu müddetçe pek çok şekilde tanımlandı. Bu tanımlamalardan birisi de "vakıf medeniyeti" idi. Elbette bu tanımlamanın hakkını verdiği muhakkak; ancak özellikle ekonomik olarak yaşanan olumsuz gelişmeler bu medeniyette de bozulmalar meydana getirdi. Merkezî bütçe ile karşılanamayan pek çok gider için vakıf gelirleri kaynak olarak kullanılmaya başlanınca bu durum vakıfların işleyişine de büyük etki yaptı. Tüm bunların yanında vakıf malını kendi malıymış gibi kullananlar, dönemin ifadesiyle "me'kel" edinenlerin sayısı da ülkedeki ekonomik bozulmayla doğru orantılı olarak arttı. Hâşim Bey Camii Vakfı özelinde yaşananlar, dönemle ilgili bazı tespitler yapma imkânı veriyor. Her şeyden evvel ne merkezde ne de mahallinde vakfiyesinin bulunamaması söz konusu kayıtların tutulması noktasında bazı aksaklıklar olduğunu göstermektedir. Vakfa yapılan müdahaleyi engellemek için yapılan girişimlerin yıllarca devam ettiği göz önüne alındığında merkez-taşra ilişkilerinin çok hızlı yürümediği ve ilgili birimler arasında yazışmaların çok uzun süre aldığı ortaya çıkmaktadır ki bu da adaletin gecikmesine neden olmaktaydı. Eğitime gelir temin etmek için kanuna aykırı iş ve işlemlerin yapılmasının özellikle yerel yöneticiler tarafından sakıncalı bulunmadığg da bu yazışmalardan ortaya çıkan başka bir sonuçtur. Vakıf gelirlerine yapılan müdahalelerde her mütevellinin bu kadar uzun soluklu uğraşıya giremeyeceği göz önüne alındığında bu örnek özelinden aslında pek çok vakıf gelirinin bu şekilde şartı haricinde yerlere harcandığının söylenmesi gerçeğe çok da aykırı

82 BOA, EV. MKT, 3406/74, 17 Mayıs 1325 (30 Mayıs 1909).

83 http://ottoman.mfa.gov.tr/Kategori.aspx?k=a1d26af9-af1b-4382-aefe-a382ff971ace (E.T. 25.09.2021).

84 Türkiye Cumhuriyeti Cumhurbaşkanlı̆ı Devlet Arşivi Başkanlığı Cumhuriyet Arşivi (BCA), 130.16.13.2/3311154.28, (21 Temmuz 1923). 
olmayacaktır. Hülasa Osmanlı Devleti’nin Rumeli coğrafyasında küçük ve geliri de görece çok fazla olmayan bir vakfa yapılan bu müdahale dönemin sosyo-ekonomik şartlarını ortaya koyarken vakıfların pek çoğunun sahipsiz kaldığı gerçeğini göstermektedir.

\section{KAYNAKLAR}

\section{Arşiv Belgeleri}

$B C A, 130.16 .13 .2 / 3311154.28$.

BOA, Bâb-ı Âlî Evrak Odası (BEO), 25/1830, 194/14518, 429/32115, 530/39685.

BOA, Dahiliye Mektubi Kalemi (DH. MKT), 268/15, 317/69, 1580/112.

BOA, Evkaf Defterleri (E. d.), 37281 .

BOA, Evkaf Cihat kalemi (EV. MKT. CHT), 234/23.

BOA, Evkaf Mektubi Kalemi (EV. MKT), 2030/4, 1391/16, 1394/21, 1449/126, 1450/98, 1548/50, 1552/102, 1557/99,

1580/41, 1582/ 7, 1582/53, 1626/110, 1632/66, 1634/37, 1648/16, 1957/63, 1838/10, 1840/19, 2030/4, 2068/79,

2108/123, 2142/113, 2235/13, 2237/94, 2270/115, 2971/121, 3119/40, 3121/85, 3265/113, 3270/250, 3406/74.

BOA, Irade Dahiliye (I. DH), $1242 / 97298$.

BOA, Irade Maarif (I. MF), 5/22.

BOA, Irade Taltifat (I. TAL), 227/51.

BOA, Maarif Tedrisat-I Ibtidaiye Kalemi (MF. IBT), 18/21, 20/34.

BOA, Marrif Mektubi Kalemi (MF. MKT), 91/47, 156/114, 237/58.

BOA, Şura-yı Devlet (ŞD), 2030/5.

BOA, Teftişat-ı Rumeli Evrakı Arzuhaller (TFR. I. ŞKT), 87/8656.

VGM Defter, Nu: 1838.

\section{Araştırma Eserleri}

ALKAN, Mustafa, "Osmanlı Vakıf Sisteminde Bozulma Üzerine Bazı Düşünceler", Türk Dünyası Araştırmaları, S. 166, Şubat 2007, ss. 67-83.

AYAR, Talip, "Cihât Mevzuatı", Vakıflar Dergisi, S. 48, Aralık 2017, ss. 145-193.

BERKI, Ali Himmet, Vakfa Dair Yazılan Eserlerle Vakfiye ve Benzeri Vesikalarda Geçen Istılah ve Tâbirler, Vakıflar Genel Müdürlüğü Neşriyatı, Ankara 1966.

GÜNAY, Hacı Mehmet, "Vakıf" C. 42, Türkiye Diyanet Vakfı Islâm Ansiklopedisi, Türkiye Diyanet Vakfı Yayınları, istanbul 2012, ss. 475-479.

Günümüz Türkçesiyle Evliya Çelebi Seyahatnamesi: Akkirman-Belgrad-Gelibolu-Manastır-Özü-SaraybosnaSlovenya-Tokat-Üsküp, 5. Kitap, 2. Cilt, Yay. Haz. Seyit Ali Kahraman, Yapı Kredi Yayınları, Istanbul 2010.

KARATAŞ, Yakup, "Sultan II. Abdülhamid'in Eğitim Politikalarının Mali Bir Veçhesi: Evkâf- I Münderisenin Maarife Terki”, Atatürk Üniversitesi Türkiyat Araştırmaları Enstitüsü Dergisi, S. 57, 2016, ss. 1839-1867.

KÖKSAL, Ahmet, "II. Meşrutiyet Dönemi'nde Vakıfların Yeniden Organizasyonuna Dair Iki Eser: Ismail Sıdkı'nın "Hatırat” ve Hamadezade Halil Hamdi Paşa’nın Layihası", Tarih Araştırmaları Dergisi, C. 33, S. 56, Ekim 2014 SS. 343-386.

-------, Maarife Kaynak Olarak Evkâf-ı Münderise, Serander Yayınları, Trabzon 2019.

ÖZ, Mehmet, "Gelenekçi Osmanlı Islahat Düşüncesinde Temlikler ve Vakıflar", Vakıflar Dergisi 80. Yıl Özel SayıII, 2019 Ankara, ss. 103-113.

ÖZTUNÇ, H. Baha, Tanzimat Döneminde Bir Rumeli Şehri Manastır Sosyo-Ekonomik Yapı (1839-1876), Kitabevi Yayınları, İstanbul 2020.

--, Rumeli II. Abdülhamid Döneminde Bir Muhabirin Rumeli Izlenimleri (1896-1907), Kitabevi Yayınları, İstanbul 2020.

ÖZTÜRK, Nazif, "Evkâf-ı Hümâyun Nezâreti”, Türkiye Diyanet Vakfı Islâm Ansiklopedisi, C. 11, Türkiye Diyanet Vakfı 
Yayınları, Istanbul 1995, ss. 521-524.

-, "XIX. Asır Osmanlı Yönetiminde Yaşanan Batılılaşma Hareketlerinin Vakıfların Üzerindeki Etkileri", islâmî Araştırmalar Dergisi, C. 8, S. 1, Ankara 1995, ss. 13-33.

SEZGIN, Ibrahim, "Paşa Livası", Türkiye Diyanet Vakfı Islâm Ansiklopedisi, C. 34. Istanbul: Türkiye Diyanet Vakfı Yayınları, İstanbul 2007, ss. 183-184.

Şemseddin Sami, Kâmusu'l-A'lâm, C. V. Mihran Matbaası, İstanbul 1314. , Kâmusu'l-A'lâm, C. III, Mihran Matbaası, İstanbul 1314.

http://ottoman.mfa.gov.tr/Kategori.aspx?k=a1d26af9-af1b-4382-aefe-a382ff971ace (E.T. 25.09.2021)

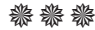




\section{EKLER}

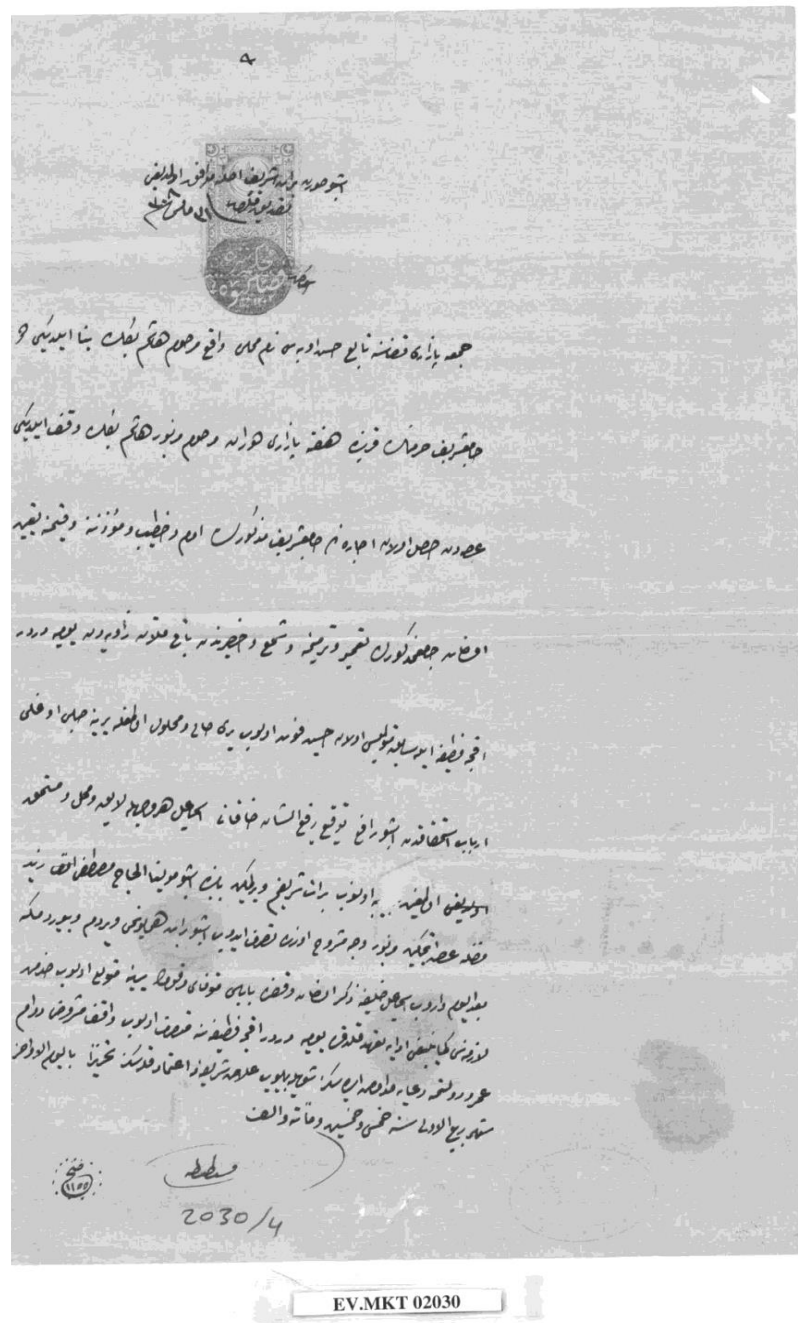

Ek 1: Haşim Bey vakfıyla ilgili 1742 tarihli berat sureti (BOA. EV. MKT., 2030/4, leff 3, 31 Mayıs 1308 (12 Haziran 1892) 


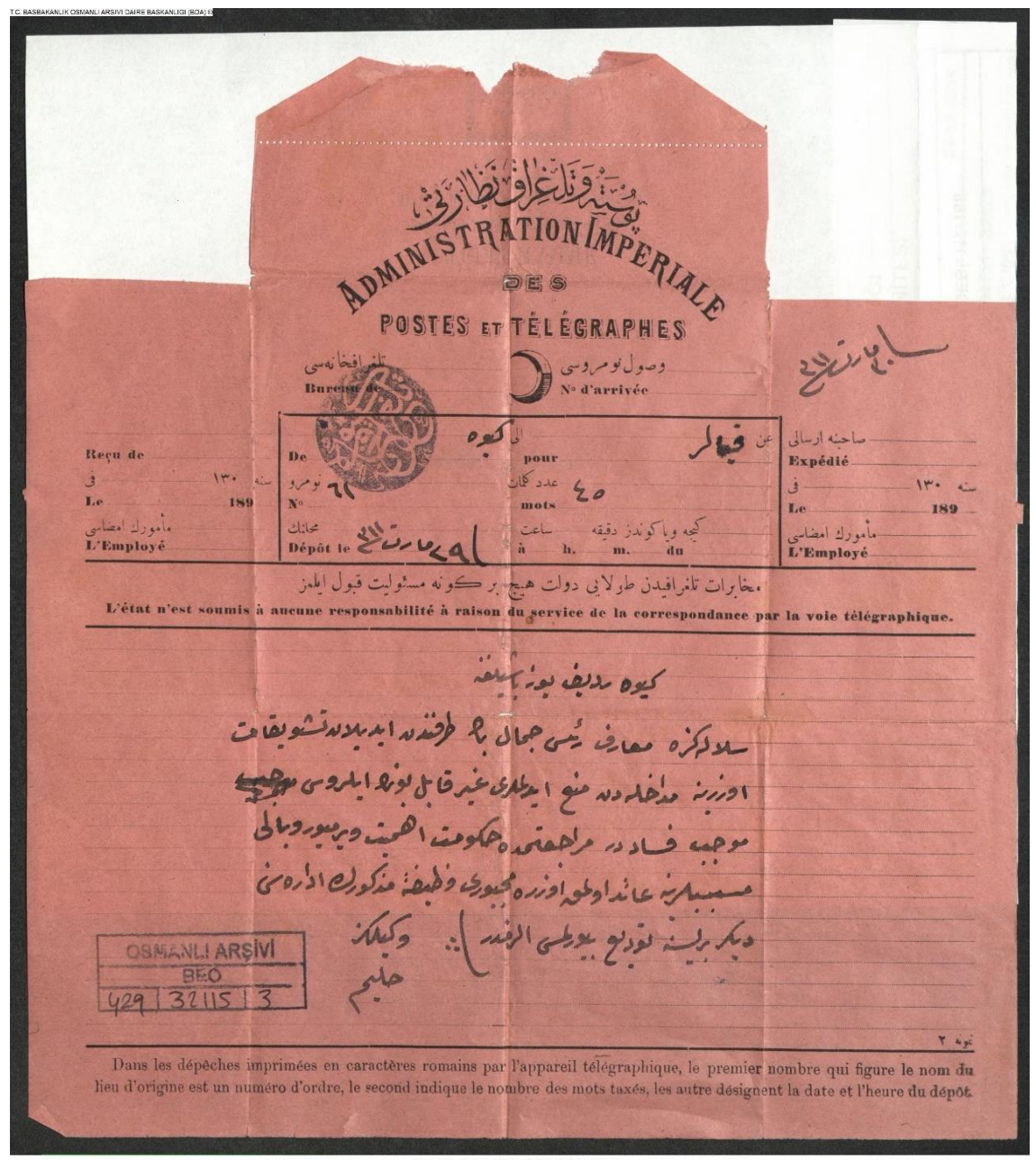

BEO.000429.032115.003

Ek 2: Haşim Bey vakfı mütevelli vekili Halim Bey’in istifa telgrafı (BOA. BEO., 429/3215, leff 3, 29 Mart 1311 (10 Nisan 1895) 
